\title{
Thermo-economic process model for thermochemical production of Synthetic Natural Gas (SNG) from lignocellulosic biomass
}

\author{
Martin Gassner, François Maréchal \\ Laboratory for Industrial Energy Systems, Ecole Polytechnique Fédérale de Lausanne \\ $\mathrm{CH}$ - 1015 Lausanne, Switzerland \\ Biomass and Bioenergy (2009), in press, doi:10.1016/j.biombioe.2009.08.004
}

\begin{abstract}
A detailed thermo-economic model considering different technological alternatives for thermochemical production of Synthetic Natural Gas (SNG) from lignocellulosic biomass is presented. First, candidate technology for processes based on biomass gasification and subsequent methanation is discussed and assembled in a general superstructure. Both energetic and economic models for biomass drying with air or steam, thermal pretreatment by torrefaction or pyrolysis, indirectly and directly heated gasification, methane synthesis and carbon dioxide removal by physical absorption, pressure swing adsorption and polymeric membranes are then developed. Performance computations for the different process steps and some exemplary technology scenarios of integrated plants are carried out, and overall energy and exergy efficiencies in the range of $69-76 \%$ and $63-69 \%$, respectively, are assessed. For these scenarios, the production cost of SNG including the investment depreciation is estimated to $76-107 € \cdot \mathrm{MWh}_{S N G}^{-1}$ for a plant capacity of $20 \mathrm{MW}_{\text {th,biomass }}$, whereas $59-97 € \cdot \mathrm{MWh}_{S N G}^{-1}$ might be reached at scales of $150 \mathrm{MW}_{\text {th, biomass }}$ and above. Based on this work, a future thermo-economic optimisation will allow for determining the most promising options for the polygeneration of fuel, power and heat.
\end{abstract}

Keywords: Biofuels, Gasification, Methane synthesis, $\mathrm{CO}_{2}$-removal, Thermo-economic modelling, Process design, Process integration

\section{Nomenclature}

$\begin{array}{ll}\text { Abbreviations } \\ \text { CFB } & \text { Circulating fluidised bed } \\ \text { FICFB } & \text { Fast internally circulating fluidised bed } \\ \text { PSA } & \text { Pressure swing adsorption } \\ \text { SNG } & \text { Synthetic natural gas } \\ \text { TSA } & \text { Temperature swing adsorption } \\ \text { vol } & \text { Volume } \\ \text { wt } & \text { Weight } \\ \text { Greek letters } \\ \Delta h^{0} \quad \text { Lower heating value } \\ \Delta \tilde{h}_{r}^{0} & \text { Standard heat of reaction } \\ \Delta h_{\text {vap }} & \text { Heat of vaporisation } \\ \Delta k^{0} & \text { Exergy value } \\ \varepsilon & \text { Energy efficiency } \\ \eta & \text { Exergy efficiency } \\ \varepsilon & \text { Mass efficiency } \\ \Phi & \text { Humidity }\end{array}$


$\varphi \quad$ Relative humidity

$\rho \quad$ Density

\section{Roman letters}

A Area

$b \quad$ Cost exponent

C Cost

$\tilde{c} \quad$ Molar fraction

$d \quad$ Diameter

$\dot{E} \quad$ Mechanical/electrical power

$e \quad$ Specific mechanical/electrical work

$\tilde{g} \quad$ Molar Gibbs free energy

$G \quad$ Gas mass flux

$h \quad$ Mass enthalpy

$h \quad$ Height

$K \quad$ Equilibrium constant

$\hat{K} \quad$ Apparent equilibrium constant

$k_{\mathrm{C} 2 / \mathrm{Cl}}$ Proportionality constant $\tilde{c}_{\mathrm{C} 2 \mathrm{H} 4} / \tilde{c}_{\mathrm{CH} 4}$

$l \quad$ Length

$\dot{m} \quad$ Mass flow

$n \quad$ Stoichiometric coefficient

$p \quad$ Pressure

$\dot{Q} \quad$ Heat

$R \quad$ Ideal gas constant

$S N \quad$ Stoichiometric number

$T$ Temperature

$t_{r 1} \quad$ Relative duration of PSA adsorption

$t_{r 2} \quad$ Relative duration of PSA recycling

$U \quad$ Overall transfer coefficient

u Velocity

$\dot{V} \quad$ Volume flow

\section{Subscripts}

$\begin{array}{ll}B M & \text { Bare module } \\ c c & \text { carbon conversion } \\ c g & \text { cold gas } \\ d & \text { Drying } \\ e l & \text { electric } \\ e q & \text { equilibrium } \\ G R & \text { Grass roots } \\ g & \text { Gasification } \\ l m & \text { log-mean } \\ m & \text { Methanation } \\ \text { sat } & \text { saturation } \\ t h & \text { thermal } \\ \text { tot } & \text { total } \\ \text { vap } & \text { vaporisation } \\ \text { Superscripts }\end{array}$

$+\quad$ Material or energy stream entering the system

- Material or energy stream leaving the system

$0 \quad$ Standard conditions

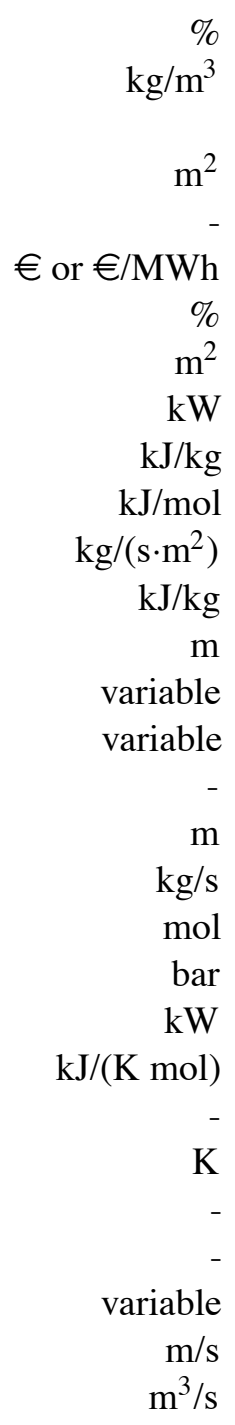




\section{Introduction}

\subsection{Background and goal}

Biomass is a widely available, renewable energy source whose use is generally accepted as a contribution to decrease greenhouse gas emissions by substituting fossil fuels. In Switzerland, the total forest area is increasing and the sustainable use of wood as an energy source could at least be doubled in the

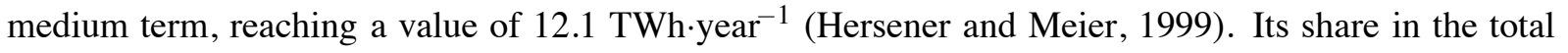
energy consumption is currently of $2.6 \%$ and it is almost exclusively used as a fuel for heating purposes. In the same time, the emissions of the transport sector account for $42 \%$ (16.5 Mtons) of the total fossil $\mathrm{CO}_{2}$ emissions. Despite the efforts to mitigate these emissions according to the Kyoto protocol, they are expected to increase (BFE, 2004) and still few solutions to enhance the use of renewable fuels are emerging. In this context, processes that convert lignocellulosic biomass into Synthetic Natural Gas (SNG), which is equal in quality to fossil natural gas, are currently under investigation (Mozaffarian and Zwart, 2003; Friedli and Biollaz, 2003; Duret et al., 2005; Heyne et al., 2008). Such a product could easily be injected into the gas grid and thus profit from the existing distribution network for transport applications. Along with an increasing market share of gas engines in the transport sector, fossil fuels could thus be partially substituted by a renewable fuel that is neutral in greenhouse gas emissions. Furthermore, as carbon dioxide has to be separated from the methane as a byproduct, a negative $\mathrm{CO}_{2}$ balance would be obtained if the $\mathrm{CO}_{2}$ is sequestrated.

Recent studies indicate that thermochemical SNG production by means of biomass gasification is technically feasible and energetic efficiencies ranging from $58 \%$ to $70 \%$ have been assessed (Mozaffarian and Zwart, 2003; Friedli and Biollaz, 2003; Duret et al., 2005; Heyne et al., 2008; Luterbacher et al., 2009). Economic analysis has further shown that the overall production costs are expected to amount to $28.1 € \cdot \mathrm{MWh}^{-1}$ for a plant capacity of $100 \mathrm{MW}_{t h}$ based on the lower heating value of wood (Mozaffarian and Zwart, 2003). Similar research on biomass gasification and subsequent Fischer-Tropsch synthesis claims that liquid fuels could be produced at conversion efficiencies of $33-50 \%$ and at a cost of 57.0 $€ \cdot \mathrm{MWh}^{-1}$ for a first commercial plant having a nominal input capacity of $367 \mathrm{MW}_{t h}$ (Tijmensen et al., 2002). The exergetic efficiency of such facilities might reach $46 \%$ (Prins et al., 2004). With total energy efficiencies of around 50\% (Hamelinck et al., 2005; Zhang et al., 2009), the production of ethanol from lignocellulosic biomass performs similar to Fischer-Tropsch products, but the co-production of SNG instead of power from the residual lignin can increase the biomass to fuel conversion to $70 \%$ (Zhang et al., 2009). Most of these conclusions are drawn from investigations of the existing technology for the subsequent process steps and considering specific scenarios. If modelled at all, the chemical transformations of the process streams have mostly been calculated assuming thermodynamic equilibrium, whereas it is known that this is not accurate in case of gasification (Schuster et al., 2001). Furthermore, only limited energy integrations have been performed, cogeneration possibilities have not been studied in detail and the process economics have been analysed with capacity-based correlations disregarding the specific process conditions.

The present work is based on the investigation of the energetic performance considering a specific process design without proper process integration (Duret et al., 2005). Its purpose is to develop detailed thermodynamic and economic models of the technological alternatives for thermochemical SNG production using woody biomass as raw material. In particular, it is aimed to identify the optimal topology and operating conditions of the process with regard to efficiency and cost. To do so, an approach based on the definition of a process superstructure and using advanced process integration techniques as well as multi-objective optimisation has been applied (Maréchal et al., 2005; Bolliger et al., 2005). This paper deals with the identification of candidate technology and its modelling in order to prepare a future thermo-economic process optimisation. 


\subsection{Methodology}

The present paper follows a previously developed methodology addressing the optimal thermo-economic process design for thermochemical fuel production from biomass (Gassner and Maréchal, 2009a). According to this approach, a preliminary analysis of the process specifications and the required steps is carried out to identify suitable technology for the process. A process superstructure including all possible options is then defined. For each unit, thermodynamic and economic models are developed. The thermodynamic model consists of two parts, i.e. energy-flow models representing the chemical and physical transformations of the chemical species from raw materials into products and an energy-integration model that represents the heat recovery in the system. In the energy-flow models, mass- and energy balances as well as physical properties and compositions of all process streams are computed using the commercial flowsheet calculation software Belsim-Vali (Belsim SA, last visited 04/2009). The energy requirements associated with these transformations define the hot and cold streams that are integrated in the energy-integration model using the heat cascade concept. In this model, utility streams whose flowrates are determined to satisfy the process units requirements are considered together with the process streams. By solving a linear programming problem, the optimal process layout and its corresponding utility system is determined with regard to operating cost (Maréchal and Kalitventzeff, 1998). The data from these thermodynamic models are further used to estimate the capital costs of the installation. Considering specific process conditions like temperatures, pressures, volume flows and gas compositions, available data from existing plants are used for a preliminary sizing of the major process equipment. The costs of the single components are then estimated from correlations (Ulrich and Vasudevan, 2004; Turton et al., 1998) and the total grass roots cost of the installation is determined (Turton et al., 1998).

The major advantage of constructing the process model with separate energy-flow and energyintegration models is that it is not necessary to define a priori a specific process topology and heat exchanger network like it is the case in conventional process simulation based on a scenario approach. With this approach, it is possible to consider a maximum number of potential solutions without setting any preferences already at an early stage of the design. Contrary, by coupling the model to an optimisation software both advantageous operating conditions of the process and its optimal layout are simultaneously determined and suboptimal solutions due to unnecessary restrictions on the topology are prevented. Therefore, the methodology is well suited for process design and has been applied successfully to fuel cell system (Maréchal et al., 2005) and power plant design (Bolliger et al., 2005).

\section{Process description}

\subsection{Process block flow}

The general layout of the thermochemical process converting lignocellulosic biomass to SNG consist of three major steps, namely gasification (endothermic), methane synthesis (exothermic) and gas separation. Representing the feedstock by a typical wood composition and using the carbon atom as reference, the overall conversion is exothermic and can be expressed as:

$$
\begin{aligned}
& \mathrm{CH}_{1.35} \mathrm{O}_{0.63}+0.3475 \mathrm{H}_{2} \mathrm{O} \stackrel{\Delta \tilde{h}_{r}^{0}=-10.5 \mathrm{~kJ} \cdot \mathrm{mol}}{\longrightarrow} \underset{\text { wood }}{-1} \\
& 0.51125 \mathrm{CH}_{4}+0.48875 \mathrm{CO}_{2}
\end{aligned}
$$

The considered raw material is wood chips whose properties are given in Table 1. Due to its high moisture content, a drying stage prior to gasification is necessary. Furthermore, the gas produced through gasification needs to be cleaned from impurities to prevent catalyst damage during methane synthesis. As biomass contains too much oxygen to be completely reformed into methane, $\mathrm{CO}_{2}$ is by-produced and must be removed before or after methanation in order to meet the quality requirements of natural gas. In Switzerland, a Wobbe Index of 13.3-15.7 kWh $\cdot \mathrm{Nm}^{-3}$ and a methane content of at least $96 \%$ vol are required for unlimited injection into the national high grid that operates at around 50 bar (SVGW, 2008). 
Table 1: Proximate and ultimate analysis of wood fuel.

\begin{tabular}{lrrr}
\hline Proximate analysis & \multicolumn{3}{c}{ Ultimate analysis } \\
\hline$\Delta h^{0}$ & $18.6 \mathrm{MJ} / \mathrm{kg}_{d r y}$ & $\mathrm{C}$ & $51.09 \% \mathrm{wt}$ \\
$\Delta k^{0 \mathrm{a}}$ & $20.9 \mathrm{MJ} / \mathrm{kg}_{d r y}$ & $\mathrm{H}$ & $5.75 \% \mathrm{wt}$ \\
Humidity $(\Phi)$ & $50.0 \% \mathrm{wt}$ & $\mathrm{O}$ & $42.97 \% \mathrm{wt}$ \\
Ash content & $0.6 \% \mathrm{wt}$ & $\mathrm{N}$ & $0.19 \% \mathrm{wt}$ \\
\hline
\end{tabular}

${ }^{\text {a }}$ Chemical exergy has been calculated using the method of Szargut and Styrylska (1964).

\subsection{Technology for the process}

\subsubsection{Wood drying}

The high moisture content of wood at the gasifier inlet severely decreases its performance (Schuster et al., 2001). This is mainly because high-temperature heat from above the process pinch is consumed for water desorption and evaporation in the gasifier, which appears as an important exergy loss (Gassner and Maréchal, 2009b). The presence of steam further tends to shift the equilibrium of the gas phase towards higher $\mathrm{H}_{2}$ and $\mathrm{CO}_{2}$ fractions and decreases the $\mathrm{CH}_{4}$ content in the gas, which has also been observed experimentally by for example Gil et al. (1997). A drying stage before gasification is thus essential. Its level is subject to optimisation since steam is also used as gasifying agent.

Steam and air drying are reported to be the most common technologies applied in sawdust or wood chips treatment (Faaij et al., 1997; Berghel and Renström, 2002; Stahl et al., 2004). The main difference between these processes is that the use of steam allows to efficiently recover the consumed heat by condensing the produced additional steam at its boiling temperature, while this energy is normally lost in air drying. However, operating temperatures are usually higher in steam dryers, and air drying might be advantageous if heat is available at lower temperatures (Berghel and Renström, 2002; Stahl et al., 2004). The performance of both processes depends on the integration with the rest of the process and its heat recovery possibilities. The optimal choice is thus determined by energy integration aspects, and models for both steam and air drying have been developed.

\subsubsection{Gasification}

Gasification of wood is an endothermal process where solid macromolecules are broken into mainly hydrogen, carbon monoxide, carbon dioxide, hydrocarbons, tars and ash. According to the requirement for a final gas product with high calorific value, adequate gasification technology should produce a nitrogen-free gas with high methane content. Air as gasifying agent is therefore not suitable and only steam and oxygen can be used for this purpose. Considering the equilibrium equations for the gas phase (Duret et al., 2005), high methane fractions are expected for gasification at low temperature and high pressure, having the further advantage that endothermicity of gasification decreases. Entrained flow gasification technology operating at high temperature is thus not adequate for the targeted application. The specified plant capacity further restricts the gasifier choice. Due to geometric considerations, fixed bed reactors are limited to about $10 \mathrm{MW}_{t h}$ (Mozaffarian and Zwart, 2003; Reimert, 1985) and thus hardly compatible with plants at industrial scale.

In this study, two types of gasifiers have been investigated, i.e. indirectly heated, steam blown FICFBgasification (Hofbauer et al., 2002) operating at around $850^{\circ} \mathrm{C}$ and atmospheric pressure and directly heated, steam-oxygen blown, pressurised CFB-gasification (Reimert and Schaub, 2009) operating at around $800^{\circ} \mathrm{C}$.

\subsubsection{Oxygen production for gasification}

Oxygen required for gasification is conventionally produced by cryogenic air separation or pressure swing adsorption (PSA). According to Kirschner (2009), on-site production with these technologies gets 
competitive at capacities of about $1000 \mathrm{Nm}^{3} \cdot \mathrm{h}^{-1}\left(0.35 \mathrm{~kg} \cdot \mathrm{s}^{-1}\right)$ and $50 \mathrm{Nm}^{3} \cdot \mathrm{h}^{-1}\left(0.02 \mathrm{~kg} \cdot \mathrm{s}^{-1}\right)$, respectively. If smaller flow rates are required, oxygen can be purchased and delivered to the plant from an external supplier. Apart from these established technologies, high temperature air separation by ceramic ion transfer membranes may be promising in the future since they can benefit from a tight integration into the plant (van Stein et al., 2002). If temporarily cheap electricity is available, electrolysis is further an interesting option since the co-produced hydrogen can be injected into the methane synthesis, where it is bound to the abundant carbon from biomass and increases the SNG yield. Even if not operated as base load, this would allow for peak shaving electricity generated from intermittent sources (like wind power) and store it as green fuel in the gas grid (Gassner and Maréchal, 2008).

\subsubsection{Thermal pretreatment before gasification}

In addition to drying, the biomass feed can optionally be processed in a second, thermochemical torrefaction or pyrolysis pretreatment step. In the literature, these technologies are often discussed in the context of improving the solid fuel's thermal and mechanical properties like heating value or grindability (Prins et al., 2006; Svoboda et al., 2009), or the direct production of bio-oil that is further refined to liquid fuel (Zhang et al., 2005). However, thermochemical processes based on gasification can benefit in general from such a pretreatment (Gassner and Maréchal, 2009b; Prins et al., 2006). In addition to completely dry the feedstock for gasification, these technologies are characterised by an onsetting endothermal decomposition at low temperature, which decreases the energy demand at high temperature in the subsequent gasification. This directly results in a higher cold gas efficiency if the required energy for torrefaction or pyrolysis is provided from excess heat below the pinch. The product gas of a directly heated gasifier is thus less oxidised, and the fuel consumption of an indirectly heated gasifier is reduced.

As demonstrated on pilot scale by Henriksen et al. (2006), one alternative is to directly close-couple a pyrolysis screw with the gasification stage and thus feed both the gaseous and solid products into the gasifier. Another one is to only feed the solid product to the gasifier and burn the by-produced low calorific gas. Although Prins et al. (2006) concluded that this option decreases the performance of directly heated fluidised bed gasification, it is promising in indirectly heated gasification since the volatiles can be used as fuel.

\subsubsection{Gas cleaning}

During gasification, tars are formed and traces of nitrogen, sulphur, chlorines and metals contained in the wood are reformed and transferred into the product gas. In order to prevent catalyst poisoning, the gas must be rid of these substances prior to methanation. Conventional cold gas cleaning includes a baghouse or sand filter to remove solid particles and partially tars, a scrubber for removal of ammonia, metals and residual tars as well as guard beds for scavenging hydrogen sulfide. Typical temperatures for these stages are $150-180^{\circ} \mathrm{C}$ at the filter inlet, $40^{\circ} \mathrm{C}$ at the scrubber outlet and around $350^{\circ} \mathrm{C}$ in the guard beds (Rauch et al., 2004; Stucki, 2005). Alternatively, hot gas cleaning by particle removal with candle filters or electrostatic precipitators, thermal or catalytic cracking of the tars and high temperature adsorption of other contaminants could be applied. This would allow for a compact process design based on pressurised gasification and methanation without intermediate gas cooling and compression. A general overview on these advanced cleaning technologies for biomass gasification is given in for example (Brown et al., 2009), extensive details on catalytic processes are reviewed by (Torres et al., 2007) and recent technology developments can be found in (Leibold et al., 2008; Pfeifer and Hofbauer, 2008; Ondrey, 2008).

\subsubsection{Methane synthesis}

Methane synthesis is a refining process to increase the calorific value of a gas containing high carbon monoxide and hydrogen fractions. The principal conversion is described by the methanation reaction (5) 
Table 2: Gasification and methanation reactions.

\begin{tabular}{lllr}
\hline Interaction & Name & Reaction & \multicolumn{1}{c}{$\Delta \tilde{h}_{r}{ }^{0}$} \\
\hline Solid-gas & Hydrogenating gasification & $\mathrm{C}(\mathrm{s})+2 \mathrm{H}_{2} \rightleftharpoons \mathrm{CH}_{4}$ & $-75 \mathrm{~kJ} / \mathrm{mol} \mathrm{(3)}$ \\
& Boudouard equilibrium & $\mathrm{C}(\mathrm{s})+\mathrm{CO}_{2} \rightleftharpoons 2 \mathrm{CO}$ & $173 \mathrm{~kJ} / \mathrm{mol}$ (4) \\
\hline Gas-gas & Methane synthesis & $\mathrm{CO}+3 \mathrm{H}_{2} \rightleftharpoons \mathrm{CH}_{4}+\mathrm{H}_{2} \mathrm{O}$ & $-206 \mathrm{~kJ} / \mathrm{mol} \mathrm{(5)}$ \\
& Ethene reforming & $\mathrm{C}_{2} \mathrm{H}_{4}+2 \mathrm{H}_{2} \mathrm{O} \rightleftharpoons 2 \mathrm{CO}+4 \mathrm{H}_{2}$ & $210 \mathrm{~kJ} / \mathrm{mol}(6)$ \\
& Water-gas shift equilibrium & $\mathrm{CO}+\mathrm{H}_{2} \mathrm{O} \rightleftharpoons \mathrm{CO} \mathrm{O}_{2}+\mathrm{H}_{2}$ & $-41 \mathrm{~kJ} / \mathrm{mol} \mathrm{(7)}$ \\
\hline
\end{tabular}

in Table 2. At typical operating temperatures of $300-400^{\circ} \mathrm{C}$ and preferably under pressure, higher hydrocarbons are broken down to $\mathrm{CO}$ and $\mathrm{H}_{2}$ and form additional $\mathrm{CH}_{4}$, as shown for ethene (6). Depending on the initial gas composition, carbon dioxide is further reformed or produced through the water-gas shift equilibrium (7).

The stoichiometric coefficients of Equations (5)-(7) allow to determine the amount of hydrogen that is needed to completely reform $\mathrm{CO}, \mathrm{CO}_{2}$ and $\mathrm{C}_{2} \mathrm{H}_{4}$ into methane. It is thus convenient to define the stoichiometric number $S N$ of the incoming gas stream in order to characterise the achievable methane yield (Boll et al., 2009), which becomes for the considered reactions:

$$
S N_{C H 4}=\frac{\tilde{c}_{H 2}}{3 \tilde{c}_{C O}+4 \tilde{c}_{C O 2}+2 \tilde{c}_{C 2 H 4}}
$$

To obtain a highly pure methane stream, this ratio must be close to unity. If it is below, the feed gas lacks hydrogen and the product gas will contain a non-negligible amount of carbon dioxide, which is the case for gases originating from wood gasification.

Methane synthesis of a $\mathrm{H}_{2} / \mathrm{CO} / \mathrm{CO}_{2}$ mixture is highly exothermic and its reactor design is critical with regard to temperature control. Common installations use product gas recycle loops or multiple intercooled reactors with prior steam addition (Boll et al., 2009; Höhlein et al., 1984). Alternatively, an internally cooled fluidised bed reactor for isothermal once-through methanation has been developed and successfully operated at pilot scale for gas produced by coal gasification (Friedrichs, 1985). Ongoing research has further proven the suitability of the latter to gases produced by wood gasification (Stucki, 2005).

\subsubsection{Carbon dioxide removal}

Removal of $\mathrm{CO}_{2}$ from natural gas is a standard operation in gas refining applications. The choice of the optimal technology depends on specific process conditions like the amount of gas treated, the partial pressure of carbon dioxide in the feed and the required purity of the produced gas (UOP LLC, last visited 04/2009). For gases containing high $\mathrm{CO}_{2}$ fractions of more than $40 \%$ as it is the case in this application, physical absorption (Sweny and Valentine, 1970), pressure swing adsorption (PSA) (Pilarczyk and Henning, 1987) and membrane processes (Bhide and Stern, 1993) can be identified as the most suitable options ${ }^{1}$. Optimal operating pressures of these processes depend considerably on the pressure of the raw gas. In general, physical absorption and membrane processes typically adapt to the gas grid pressure of 50 bar, while the maximum pressure in a PSA cycle is of 5-6 bar. Contrary to chemical absorption considered by (Heyne et al., 2008), all this processes are almost neutral in thermal energy.

\footnotetext{
${ }^{1}$ Although chemical absorption with amines is a widely used technology for acid gas removal, it is not considered here since it is better suited for feeds at lower partial pressure of $\mathrm{CO}_{2}$.
} 


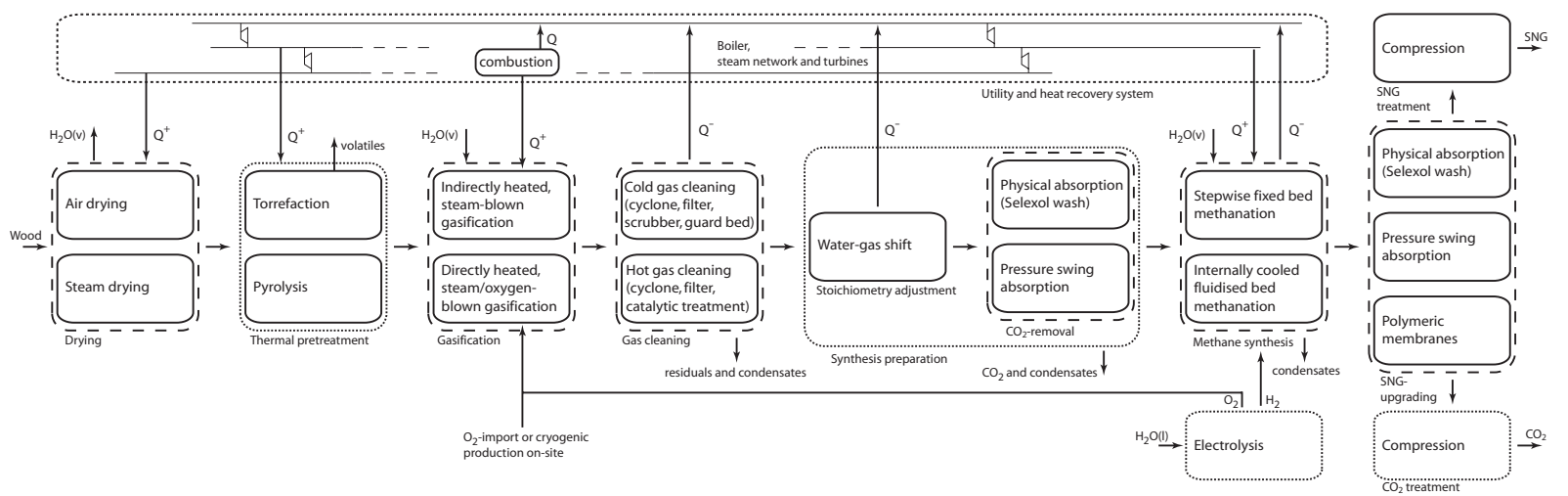

Figure 1: Process superstructure including main process streams without recycling loops. Dashed lines assemble investigated alternatives for different process sections and dotted lines indicate optional units.

\subsection{Process superstructure}

From the preceding considerations, a general process superstructure is identified and depicted in Figure 1. The internal subsystem configuration like recycling and the integration of the utility system including hot and cold utilities as well as cogeneration possibilities by a steam Rankine cycle is not detailed. In addition to the mandatory operations outlined in Section 2.1, the superstructure includes the optional thermal pretreatment and also the possibility to adjust the stoichiometry of the producer gas prior to methanation. Disregarded by (Mozaffarian and Zwart, 2003; Friedli and Biollaz, 2003; Duret et al., 2005; Stucki, 2005), this is a popular option for coal-derived producer gas that is recently also considered for biomass (Heyne et al., 2008; TRE, 2009).

\section{Process modelling}

\subsection{Energy-flow models}

As detailed in the applied methodology, the energy-flow models aim at defining the chemical and physical transformations occurring in the units of the superstructure. They determine the heat transfer requirements in terms of heat load and temperatures to be satisfied by the heat recovery and utility system, and further provide the necessary data for the equipment rating. In this regard, the process design method implies a trade-off between the details of the unit models and the degrees of freedom left to the process design. It requires models that are simple and robust enough to allow for evaluating different process configurations, and precise enough to accurately represent the performance of the process units. The proposed models realise this compromise without requiring detailed simulations of the heat and mass transfer dynamics and the chemical reaction kinetics. This approach is demonstrated in the following sections, and general assumptions and parameters are shown in Table 3.

\subsubsection{Drying}

Air drying processes are governed by the transfer of water in the solid and differences in vapour pressure at its surface and the surrounding air. The equilibrium vapour pressure at the solid's surface depends on temperature and is given by sorption isotherms. To quantify this equilibrium, an empiric equation has 
Table 3: General assumptions and key parameters for the energy-flow models.

\begin{tabular}{|c|c|c|}
\hline$\overline{\text { Section }}$ & Specification & Value \\
\hline \multirow[t]{2}{*}{ Air drying } & Wood outlet temperature & $\overline{T_{\text {air }, \text { out }}}$ \\
\hline & Dryer pressure drop & $100 \mathrm{mbar}$ \\
\hline \multirow[t]{3}{*}{ Steam drying } & Wood outlet temperature & $T_{H 2 O, s a t}$ \\
\hline & Dryer pressure drop & 50 mbar \\
\hline & Heat loss (based on energy for steam heating) & $18 \%$ \\
\hline \multirow[t]{2}{*}{ Gasification } & Pressure drop in fluidised bed reactors & 150 mbar \\
\hline & Excess pressure of injected steam & 12 bar \\
\hline \multirow[t]{2}{*}{ Gasification, indirectly heated } & Reactor heat loss (based on transferred heat) & $10 \%$ \\
\hline & $\mathrm{N}_{2}$-content in cold gas & $0.5 \%$ vol \\
\hline Gasification, directly heated & Reactor heat loss (based on $\Delta h_{\text {wood }}^{0}$ ) & $1 \%$ \\
\hline \multirow[t]{3}{*}{ Gas cleaning } & Filter inlet temperature & $150^{\circ} \mathrm{C}$ \\
\hline & Pressure drop & 100 mbar \\
\hline & Biodiesel consumption in scrubber & $4.7 \mathrm{ml} \cdot \mathrm{m}_{\text {gas }}^{-3}$ \\
\hline \multirow[t]{2}{*}{ Methane synthesis } & Reactor pressure drop & $150 \mathrm{mbar}$ \\
\hline & Energy efficiency of electrolysis & $85 \%$ \\
\hline \multirow[t]{4}{*}{ Physical absorption } & $\mathrm{CO}_{2}$-solubility in Selexol & $0.18 \mathrm{~mol} \cdot \mathrm{l}^{-1} \cdot \mathrm{bar}^{-1}$ \\
\hline & Relative solubility $\mathrm{CO}_{2} / \mathrm{CH}_{4}$ & 17.1 \\
\hline & Regeneration pressure & 1 bar \\
\hline & Pressure drop through column & neglected \\
\hline \multirow[t]{3}{*}{ Pressure swing absorption } & Adsorption pressure & 5.5 bar \\
\hline & Purging pressure & 0.2 bar \\
\hline & $\mathrm{CO}_{2}\left(\mathrm{CH}_{4}\right)$-slip fraction during adsorption (purging) & $0.2 \% \mathrm{vol}$ \\
\hline \multirow[t]{5}{*}{ Polymeric membranes } & Material: cellulose acetate (polysulfone) for bulk-CO & $\mathrm{H}_{2}$ ) separation \\
\hline & $\mathrm{CO}_{2}$-permeability & $9.0(5.6)$ barrer \\
\hline & Selectivity $\mathrm{CO}_{2} / \mathrm{CH}_{4}, \mathrm{CO}_{2} / \mathrm{CO}, \mathrm{CO}_{2} / \mathrm{N}_{2}$ & $21.1(22.4)$ \\
\hline & Selectivity $\mathrm{H}_{2} / \mathrm{CH}_{4}$ & $6.2(56.0)$ \\
\hline & Effective membrane thickness & $1000 \AA$ \\
\hline \multirow[t]{2}{*}{ All sections } & Heat exchanger pressure drop & neglected \\
\hline & Isentropic efficiency of turbomachinery & $80 \%$ \\
\hline Thermodynamic models & $\begin{array}{l}\text { Ideal gas law, liquid phase in unsymmetric conventio } \\
\text { solubilities from (Sander, 1999) }\end{array}$ & \\
\hline
\end{tabular}


been fitted to data from (Krischer, 1978):

$$
\begin{aligned}
\Phi_{\text {wood }} & =2.865 \cdot 10^{-2} \varphi_{\text {air }}^{1 / 2} \\
& +\left(2.307 \cdot 10^{-1}-1.273 \cdot 10^{-3}(T-273)\right) \varphi_{\text {air }} \\
& -2.519 \cdot 10^{-1} \varphi_{\text {air }}^{2} \\
& +\left(2.199 \cdot 10^{-1}+8.630 \cdot 10^{-4}(T-273)\right) \varphi_{\text {air }}^{3}
\end{aligned}
$$

In this equation, $\Phi_{\text {wood }}$ terms the wood humidity in $\mathrm{kg}_{H 2 O} \cdot \mathrm{kg}_{\text {tot }}^{-1}, \varphi_{\text {air }}$ the relative humidity of air in $\%$ and $T$ the air temperature in $\mathrm{K}$. Limited residence times in dryers prevent however that thermodynamic equilibrium is reached, and mass transfer needs to be modelled in order to estimate the outlet moisture content. In analogy to the energy transfer equation in heat exchanger calculations, the amount of transferred moisture can be written as:

$$
\frac{\dot{m}_{H 2 O, v a p}}{\dot{m}_{\text {air }}}=U_{p} \Delta p_{l m}
$$

where $U_{p}$ terms an overall mass transfer coefficient and $\Delta p_{l m}$ the countercurrent log-mean difference of partial pressures, i.e.:

$$
\Delta p_{l m}=\frac{\Delta p_{1}-\Delta p_{2}}{\ln \left(\Delta p_{1} / \Delta p_{2}\right)}
$$

In this equation, $\Delta p_{1}$ terms the difference of partial pressures at the air outlet and $\Delta p_{2}$ at the air inlet. $U_{p}$ has been fitted to data of a direct rotary drum dryer for wood (Faaij et al., 1997) and a value of $11.16 \cdot 10^{-3}$ bar $^{-1}$ has been determined.

Contrary to air dryers, the gas phase in steam dryers is homogeneous and always above the moisture's boiling temperature. The drying process is thus controlled by heat transfer. As for air drying, an overall transfer coefficient $U_{T}$ based on the amount of energy needed to evaporate the moisture has been introduced:

$$
\frac{\Delta h_{\text {vap }} \dot{m}_{H 2 O, v a p}}{\dot{m}_{\text {steam }}}=U_{T} \Delta T_{l m}
$$

$U_{T}$ has been fitted to data for a pilot-scale steam dryer (Berghel and Renström, 2002) and a value of 1117 $\mathrm{J} \cdot \mathrm{kg}^{-1} \mathrm{~K}^{-1}$ has been determined.

The performance of both dryers is evaluated in terms of drying efficiency $\varepsilon_{d}$ and the specific mechanical energy consumption $e^{+}{ }_{d}$. The former is defined as the ratio between the energy used for moisture evaporation and the total thermal energy supplied to the dryer (Eq. 12) and the latter as the mechanical work consumed per unit mass of evaporated moisture (Eq. 13):

$$
\begin{aligned}
\varepsilon_{d} & =\frac{\Delta h_{v a p} \dot{m}_{H 2 O, v a p}}{\dot{Q}^{+}{ }_{d}} \\
e^{+}{ }_{d} & =\frac{\dot{E}^{+}{ }_{d}}{\dot{m}_{H 2 O, v a p}}
\end{aligned}
$$

Figure (2) compares the computed performance of the drying processes as a function of the temperature of the heating fluid at the dryer inlet. In case of steam drying, $\varepsilon_{d}$ is slightly decreasing with temperature and situated at around $60 \%$. The performance of air drying is expected to increase with temperature and reaches efficiencies above $70 \%$ at high temperatures. For both systems, the specific mechanical energy consumption is decreasing with temperature and is in the order of $200 \mathrm{~kJ} \cdot \mathrm{kg}_{\mathrm{H} 2 \mathrm{O}}^{-1}$, vap .

\subsubsection{Gasification}

The thermochemical decomposition of solid feedstock is a complex process that is governed by chemical kinetics and heat- and mass-transfer dynamics. As discussed by for example Pierucci and Ranzi (2008), 


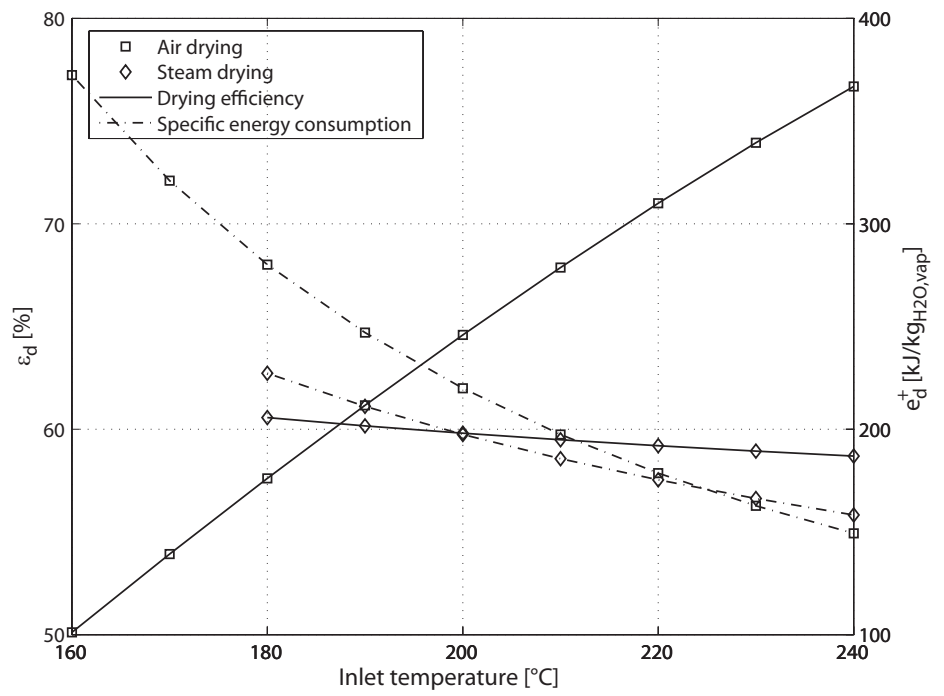

Figure 2: Drying efficiency and specific mechanical energy consumption for steam and air drying.

accurate models to predict the performance of gasifiers require to handle the description of a large number of species and reactions, and thus to numerically solve a large system of differential equations. Such models, however, are not appropriate for process design purposes. In flowsheeting applications, the product composition and yield is therefore often simply fixed or computed through an equilibrium approach. Although sometimes assumed (e.g. (Schuster et al., 2001)), thermodynamic equilibrium is yet not a valid assumption for fixed and fluid bed gasification that are typically operating below $100 \% \mathrm{C}$, and various corrections have been proposed. Many authors, among recent studies (Li et al., 2004; Pellegrini and de Oliveira Jr., 2007; Pröll and Hofbauer, 2008), therefore fix the carbon conversion and/or the fraction of methane and higher hydrocarbons, or correct the equilibrium constant with a multiplication factor (Jarungthammachote and Dutta, 2007; Huang and Ramaswamy, 2009). Introduced by Gumz (1950) and discussed for its application to biomass gasification by for instance (Gassner and Maréchal, 2009b; Prins et al., 2007) and in more detail by (Bacon et al., 1982; Kersten, 2002; Brown, 2007), a thermodynamically more significant approach is to correct the equilibrium temperature by introducing a temperature difference $\Delta T_{e q}$ to equilibrium, i.e.:

$$
\hat{K}_{p}=K_{p}\left(T_{g}+\Delta T_{e q}\right)
$$

where $K_{p}$ is the theoretical equilibrium constant and $\hat{K}_{p}$ the apparent one corresponding tom the experimentally observed composition at the gasification temperature $T_{g}$. They are computed with:

$$
\begin{aligned}
K_{p}(T) & =\exp \left(\frac{\sum_{j} n_{j} \tilde{g}_{j}^{0}(T)-\sum_{i} n_{i} \tilde{g}_{i}^{0}(T)}{R T}\right) \\
\hat{K}_{p} & =\frac{\prod_{j} p_{j}^{n_{j}}}{\prod_{i} p_{i}^{n_{i}}}
\end{aligned}
$$

where $n$ are the stoichiometric coefficients of the reactants $i$ and products $j, p$ their partial pressure, $\tilde{g}$ the Gibbs free energy and $R$ the ideal gas constant. Assuming that wood is converted into the gaseous components $\mathrm{H}_{2}, \mathrm{CO}, \mathrm{CO}_{2}, \mathrm{CH}_{4}, \mathrm{C}_{2} \mathrm{H}_{4}, \mathrm{H}_{2} \mathrm{O}, \mathrm{N}_{2}$ and residual solid carbon $\mathrm{C}(\mathrm{s})$, four model equations are needed in addition to the atomic balances in order to determine the product yield and composition. Among the different possibilities, the hydrogenating gasification (3), Boudouard (4), steam ethene reforming (6) and water-gas shift (7) equilibria of Table 2 could be chosen as an independent set.

According to the heat of reaction of these equilibria, higher gasification temperatures would favour the formation of $\mathrm{H}_{2}$ and $\mathrm{CO}$, while $\mathrm{CO}_{2}, \mathrm{CH}_{4}, \mathrm{C}_{2} \mathrm{H}_{4}$ and - with the typical wood composition of Table 1 $-\mathrm{C}(\mathrm{s})$ are favoured at lower temperatures. This behaviour is generally confirmed for $\mathrm{H}_{2}, \mathrm{CH}_{4}, \mathrm{C}_{2} \mathrm{H}_{4}$ and 
C(s) by some extensive studies on fluidised bed gasification (Gil et al., 1997; Li et al., 2004; Rapagnà et al., 2000). In indirectly heated gasification, this trend has also been roughly confirmed for $\mathrm{CO}$ and $\mathrm{CO}_{2}$ (Rapagnà et al., 2000), whereas directly heated gasification with oxygen generated more $\mathrm{CO}_{2}$ and less CO with increasing temperature (Gil et al., 1997). These differences can partly be explained by the increasing oxygen content with temperature due to the direct heating, but must also be attributed to higher reaction rates that favour the conversion towards $\mathrm{CO}_{2}$.

A large amount of different operating conditions has been investigated in the literature, yet surprisingly few information is available on the influence of pressure. To our knowledge, no systematic dataset has been published, and the few measurements at moderate and only slightly varying pressure do not allow to confirm the expectation from Eq. (16) that namely the $\mathrm{CH}_{4}$-fraction increases with increasing pressure. Indeed, it can be argued that the pressure tends to accelerate the reaction rates, thus improves the conversion towards equilibrium and counterbalances the positive equilibrium effect of pressure on methane yield. We therefore adopt a more conservative hypothesis concerning methane formation in the model, which is to consider not the partial pressure, but the molar fractions as activity of the species in the gas phase. A $\hat{K}_{\tilde{c}}$ is therefore defined, i.e.:

$$
\hat{K}_{\tilde{c}}=\frac{\prod_{j} \tilde{c}_{j}^{n_{j}}}{\prod_{i} \tilde{c}_{i}^{n_{i}}}=\hat{K}_{p} \cdot p^{-\left(\sum_{j} n_{j}-\sum_{i} n_{i}\right)}
$$

and used instead of $\hat{K}_{p}$. Equation (14) is therefore rewritten as:

$$
\hat{K}_{\tilde{c}}=K_{p}\left(T_{g}+\Delta T_{e q}\right)
$$

in which $K_{p}$ is still evaluated with Equation (15).

By applying this approach to four independent equilibrium reactions of Table 2, it is feasible to determine the reaction extent and the product composition of gasification. However, it has been observed that the observed $\mathrm{C}_{2} \mathrm{H}_{4}$-fraction is excessively far from its equilibrium composition in terms of temperature, and that the amount of residual carbon is numerically sensible and difficult to handle since it is only implicitly represented in the equations. In order to avoid a considerable deterioration of the robustness of the model, the corrected equilibrium reactions are therefore only used with the hydrogenating gasification (3) and the water-gas shift reaction (7). The amount of higher hydrocarbons represented by ethene is assumed to be proportional to the methane yield (19), and the carbon conversion efficiency is considered constant (20):

$$
\begin{aligned}
& \tilde{c}_{C 2 H 4}=k_{C 2 / C 1} \tilde{c}_{C H 4} \\
& \dot{m}_{\text {carbon,residual }}=\left(1-\varepsilon_{c c}\right) \dot{m}_{\text {carbon,biogenic }}
\end{aligned}
$$

By fitting the model parameters $\left(\Delta T_{e q,(3)}, \Delta T_{e q,(7)}, k_{C 2 / C 1}\right.$ and $\left.\varepsilon_{c c}\right)$ to data of existing plants, both correct product yields and energy balances around the nominal operating points are obtained. Table 4 shows the good agreement of the reconciliation reached for the considered gasifiers with the values of the model parameters of Table 5. It is thereby interesting to see that the distance to equilibrium of the reactions are identical in the two models although the principles of gasification are different. This means that the bed plays the same catalytical role in the gasifier and that the stability of methane in the gas phase preventing its decomposition is the same in the two gasifiers which are operating at similar temperatures.

Figure 3 depicts the dependence of the gasifier outlet composition in the interval of $\pm 50^{\circ} \mathrm{C}$ of the nominal gasification temperature. For both gasifiers, lower operating temperatures are increasing the hydrocarbon and $\mathrm{CO}_{2}$ content and decreasing the $\mathrm{H}_{2}$ and $\mathrm{CO}$ fractions, resulting in an increased volumetric calorific value of the gas. Comparing both gasifiers, it can be seen that the $\mathrm{CO}$ and $\mathrm{CO}_{2}$ fractions and thus the degree of oxidation is considerably higher in directly heated gasification. Accordingly, its product gas has a lower stoichiometric number than in indirectly heated gasification, which will lead to a lower $\mathrm{CH}_{4}$ concentration after methanation. Figure 4 shows the cold gas efficiency $\varepsilon_{c g}$, defined as the ratio of the chemical energy contained in the cold product gas and the raw material (21), for variations 
Table 4: Reconciliation of the producer gas compositions at nominal $T_{g}$ and $p_{g}=1 \mathrm{bar}$ (Data / Calculation [\%vol]).

\begin{tabular}{lccc}
\hline Gasifier & $\begin{array}{c}\text { indirectly heated } \\
\text { (Rauch, written around 2004) }\end{array}$ & $\begin{array}{c}\text { directly heated } \\
\text { (Reimert and Schaub, 2009) }\end{array}$ & directly heated $\left(\mathrm{O}_{2}\right)$ \\
$T_{g}$ & $850^{\circ} \mathrm{C}$ & $800^{\circ} \mathrm{C}$ & $800^{\circ} \mathrm{C}$ \\
\hline $\mathrm{C}_{2} \mathrm{H}_{4}$ & $1.8 / 1.9$ & $2.0 / 1.9$ & $-/ 4.5$ \\
$\mathrm{CH}_{4}$ & $8.8 / 9.6$ & $4.2 / 4.0$ & $-/ 9.5$ \\
$\mathrm{H}_{2}$ & $37.3 / 38.5$ & $14.8 / 14.7$ & $-/ 25.8$ \\
$\mathrm{CO}$ & $29.4 / 27.4$ & $15.4 / 16.0$ & $-/ 32.3$ \\
$\mathrm{CO}$ & $16.2 / 15.8$ & $15.0 / 14.7$ & $-/ 24.0$ \\
$\mathrm{~N}_{2}$ & $-{ }^{\mathrm{a}} / 2.9$ & $39.6 / 40.3$ & $-/ 0.1$ \\
$\mathrm{H}_{2} \mathrm{O}$ & $3.6 / 3.9$ & $-/ 8.4$ & $-/ 3.8$ \\
\hline$\Delta h^{0}\left[\mathrm{MJ} \cdot \mathrm{Nm}^{-3}\right]$ & $12.0 / 12.2$ & $6.2 / 6.2$ & $-/ 12.9$ \\
$S N[-]$ & $0.24 / 0.26$ & $0.13 / 0.13$ & $-/ 0.13$ \\
\hline
\end{tabular}

a Although no nitrogen is introduced by the gasification agent, some $\mathrm{N}_{2}$ is used for inertisation of the raw material, which prohibits to attain the criterion on the Wobbe Index at the process outlet. In the remainder of this work, a cut-down to $0.5 \%$ vol of the dry gas by inertisation with $\mathrm{CO}_{2}$ is assumed feasible.

Table 5: Reconciled gasification model parameters.

\begin{tabular}{lcc}
\hline Gasifier & indirectly heated & directly heated \\
\hline$\Delta T_{e q,(3)}$ & $-280^{\circ} \mathrm{C}$ & $-280^{\circ} \mathrm{C}$ \\
$\Delta T_{e q,(7)}$ & $-112^{\circ} \mathrm{C}$ & $-112^{\circ} \mathrm{C}$ \\
$k_{C 2 / C 1}$ & 0.205 & 0.476 \\
$\varepsilon_{c c}$ & $90.3 \%$ & $93.0 \%$ \\
\hline
\end{tabular}

of temperature and inlet wood humidity around the normal operating point.

$$
\varepsilon_{c g}=\frac{\Delta h_{\text {gas }}^{0} \dot{m}_{\text {gas }}^{-}}{\Delta h_{\text {wood }}^{0} \dot{m}_{\text {wood }}^{+}}
$$

According to the figure, the conversion of chemical energy is more efficient in directly heated gasification and situated around $80 \%$, while its value for indirectly heated gasification is in the range of $70-80 \%$. As discussed in Section 2.2.1, increasing wood humidity is markedly deteriorating the performance of both gasifiers.

\subsubsection{Oxygen production for gasification}

Since no major advantages from the integration of the SNG production with a cryogenic or adsorptive air separation plant is expected, oxygen has been considered as a utility and the cost figures from Kirschner (2009) are used directly. If by-produced oxygen from electrolysis is used, an energy efficiency of $85 \%$ based on the lower heating value of hydrogen and the power input is assumed, and the excess heat is considered available at $120^{\circ} \mathrm{C}$. A detailed analysis of this particular process configuration is reported in (Gassner and Maréchal, 2008) and thus not discussed in this paper.

\subsubsection{Thermal pretreatment before gasification}

Compared to gasification, torrefaction and pyrolysis are processes where the solid decomposition is less advanced and multiple condensable and non-condensable products are formed. An equilibrium approach to predict accurate product yields and composition is not adequate, and the processes are represented by simple conversion ratios for fixed operating conditions. From experimental torrefaction data at $260 \mathrm{C}$ (Bourgois and Guyonnet, 1988), a dry solid yield of $87 \%$ has been derived, whereas the carbon mass fraction in the product is increased by $5.7 \%$ compared to its initial hydrocarbon composition, and the 


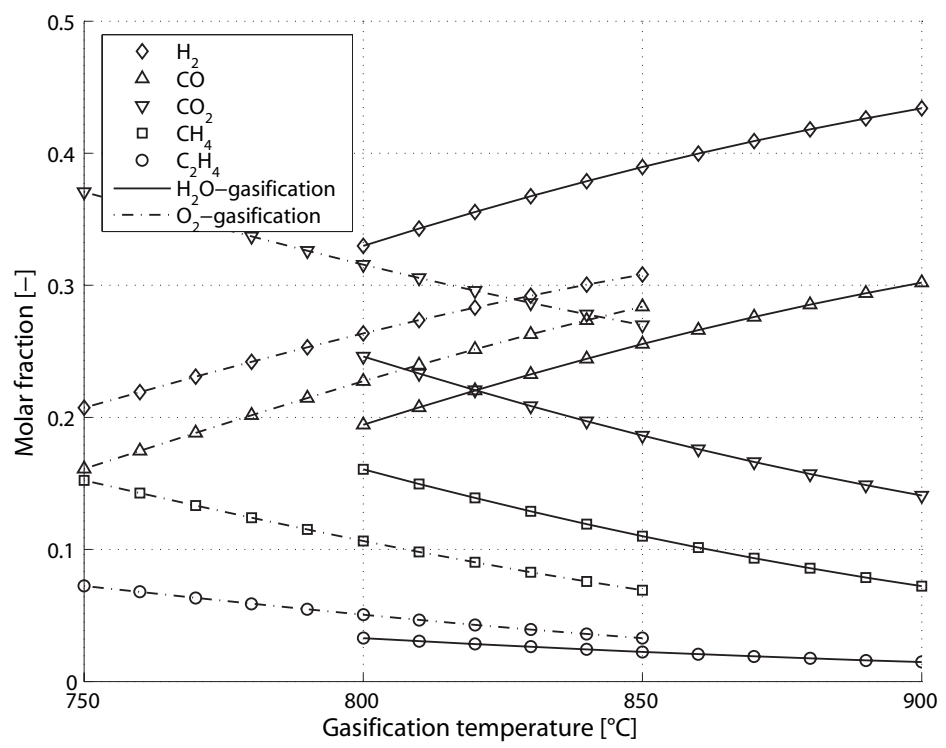

Figure 3: Molar compositions of the dry gas from gasification.

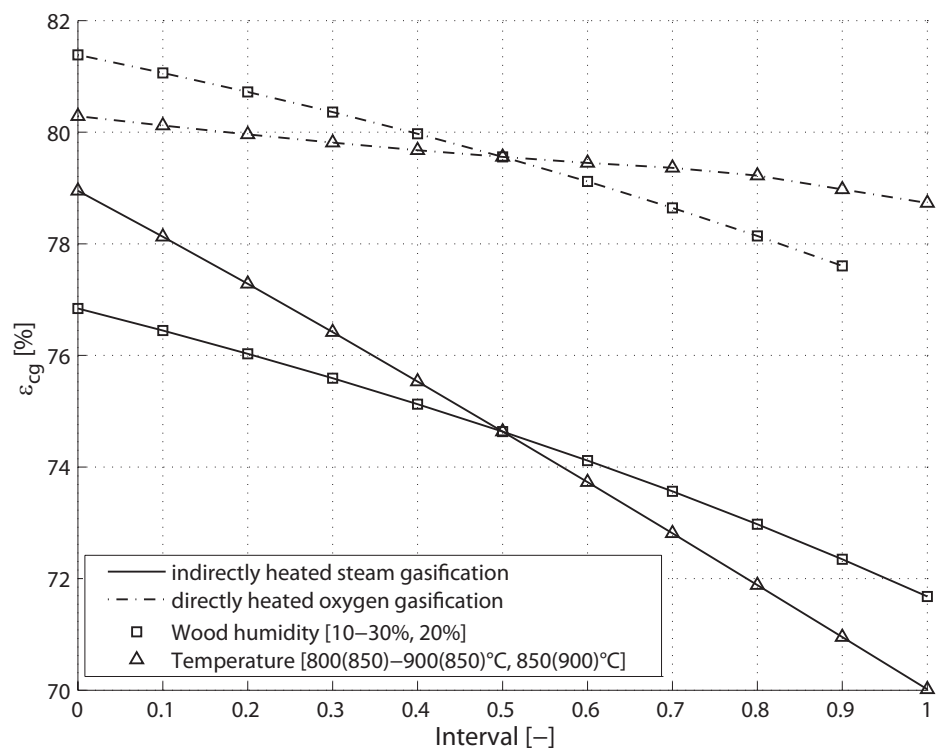

Figure 4: Cold gas efficiencies in parameter domain. 
hydrogen and oxygen fractions are decreased by $8.4 \%$ and $5.8 \%$, respectively. The moisture in the vapour phase is accompanied by acetic acid, methane, carbon mono- and dioxide, whereas $50.1 \%$ and $17.5 \%$ of the biogenic hydrogen and oxygen is bound in methane and carbon monoxide, respectively. For screw pyrolysis (Henriksen et al., 2006), it is assumed that the volatile fraction of the solid is completely transferred into the vapour phase, and a simplified model for calculating the heat requirement for the decomposition is used (Gassner and Maréchal, 2009b).

\subsubsection{Gas cleaning}

Since the conversion of impurities and tars are negligible for energy concerns, they have not been included in the models. However, the thermodynamic transformations that the cleaning operations imply obviously need to be considered. If cold cleaning is applied, the producer gas from gasification is cooled to $150^{\circ} \mathrm{C}$ before entering the filter. Downstream of this unit, no thermal energy can be recovered and the gas is cooled to atmospheric temperature in the scrubber, where it also reaches water saturation. In the model, it has been assumed that this heat is lost, although part of it would be available as moderately heated water leaving the scrubber. If hot cleaning is applied, the sensible heat of the gas is supposed to be entirely recoverable.

\subsubsection{Methane synthesis}

Using a similar modelling approach like in gasification, the outlet composition of the methane synthesis reactor has been computed with equilibrium equations. However, methanation is a catalytic process and the equilibrium condition is a reasonable assumption if the amount of catalytic material is sufficient. Experimental data from a laboratory reactor confirm this assumption (Duret et al., 2005). No model constants have therefore been introduced and the methanation (5), the steam ethene reforming (6) and the water-gas shift reaction (7) have been supposed to be in chemical equilibrium. In order to avoid carbon deposition, steam must be added to the producer gas prior to the reactor which disfavours the formation of methane. The minimum required amount is estimated based on the equilibrium data presented by Mozaffarian and Zwart (2003).

\subsubsection{Carbon dioxide removal}

All considered carbon dioxide removal processes are based on local diffusion processes and are heavily dependent on diffusion and absorption kinetics. A detailed model requires dynamic simulation, which is too complicated and not appropriate for flowsheet calculations in process design studies. For this reason, the $\mathrm{CO}_{2}$-removal models are developed on the basis of overall performance and characteristic operation parameters.

For physical absorption, the solubilities of carbon dioxide and methane in the classic solvent Selexol reported by Sweny and Valentine (1970) are used to calculate the multicomponent separation in an absorption tower. Applying the Kremser method (Diab and Maddox, 1982), its performance is determined with respect to the number of theoretical trays and the relative solvent flow rate. While the residual humidity in the saturated gas is completely removed by the solvent, the solubility of the other non-condensable species $\left(\mathrm{H}_{2}, \mathrm{CO}, \mathrm{N}_{2}\right)$ is very low and therefore neglected in the modelling. In order to achieve a high product recovery, a typical process layout with a flash drum at moderate pressure for recycling the dissolved $\mathrm{CH}_{4}$ is considered (Newman, 1985).

Pressure swing adsorption is a discontinuous process that removes the carbon dioxide by its adsorption under pressure following regeneration of the adsorbent at subatmospheric pressure. The purity and the amount of methane recovered in the outlet stream is essentially determined by the durations of the adsorption, recycling and purging periods. As shown on Figure 5, two parameters, i.e. $t_{1}$ and $t_{r 2}$, are introduced and fix the relative durations of these periods. The time-averaged flow of species $i$ that leaves 


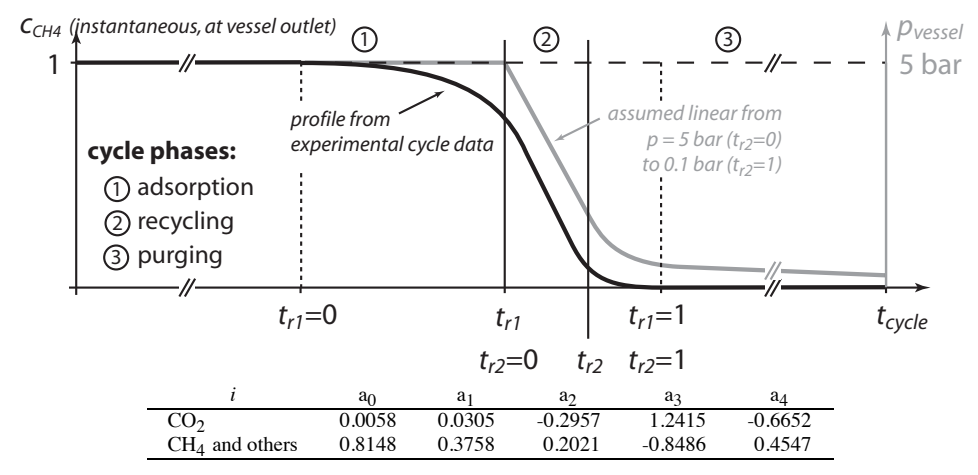

Figure 5: Illustration of the phenomenological model for PSA and coefficients for the regression of $f\left(i, t_{r}\right)=a_{0}+a_{1} t_{r}+a_{2} t_{r}^{2}+a_{3} t_{r}^{3}+a_{4} t_{r}^{4}$ used in Equations (22) and (23).

the adsorber system $\left(\dot{m}_{i, \text { out }}\right)$ or is recycled to its inlet $\left(\dot{m}_{i, \text { rec }}\right)$ is then determined by a relation of the form:

$$
\begin{aligned}
& \dot{m}_{i, \text { out }}=f\left(i, t_{r 1}\right) \dot{m}_{i, \text { in }} \\
& \dot{m}_{i, r e c}=f\left(i, t_{r 2}^{\prime}\right) \dot{m}_{i, \text { in }}-\dot{m}_{i, \text { out }} \\
& \text { with } t_{r 2}^{\prime}=\left(1-t_{r 1}\right) t_{r 2}+t_{r 1}
\end{aligned}
$$

where $f\left(i, t_{r}\right)$ represents the relative amount of species $i$ that has left an adsorption vessel at $t$ during one cycle. A numeric integration of pilot plant data reported by Pilarczyk and Henning (1987) for biogas separation with a carbon molecular sieve adsorbent has allowed for regressing $f(i, t)$ to a polynomial of $4^{\text {th }}$ degree whose coefficients are shown on Figure 5.

For SNG upgrade with membranes, a general design model for hollow-fibre modules proposed by Pettersen and Lien (1994) has been implemented in a superstructure of possible membrane arrangements. At the example of this separation technology, the integration of the crude SNG separation with the reactive process steps is discussed and optimised in a separate work (Gassner et al., 2009). As also for the PSA process, it is assumed that the saturated feed is first dried by temperature swing adsorption (TSA) over aluminium-oxide, for which $11 \mathrm{MJ} \cdot \mathrm{kg}_{\mathrm{H} 2 \mathrm{O}}^{-1}$ at $160-190^{\circ} \mathrm{C}$ are required (Bart and von Gemmingen, 2009).

Exploring these models, it has been determined that the Wobbe Index of $13.3 \mathrm{kWh} \cdot \mathrm{Nm}^{-3}$ can be met with all considered technologies. For upgrading the crude gas from atmospheric pressure to grid quality and pressure by PSA or physical absorption, a specific mechanical power consumption in the order of $600-800 \mathrm{~kJ} \cdot \mathrm{kg}_{\text {crudeSNG }}^{-1}$ is required and leads to an approximate composition of $84 \% \mathrm{vol} \mathrm{CH}_{4}$, $12 \% \mathrm{H}_{2}, 0.2 \% \mathrm{CO}$ and $3.5 \%$ of inerts. With these two technologies, the residual hydrogen from the equilibrium synthesis is however not separated from methane, which limits its purity to around $86 \%$ vol $\mathrm{CH}_{4}$. For gas upgrading to a methane content of $96 \% \mathrm{vol}$, a final membrane stage for hydrogen removal can be used, from which the $\mathrm{H}_{2}$-rich permeate is recycled to the methane synthesis. According to the information provided by Abetz et al. (2006), matrimid or polysulfone membranes are a reasonable choice for this purpose. Alternatively, an upgrading system entirely based on cellulose acetate membranes can be used, for which a specific mechanical energy consumption of $750-1100 \mathrm{~kJ} \cdot \mathrm{kg}_{\text {erudeSNG }}^{-1}$ depending on the targeted SNG-recovery in the separation stage has been assessed (Gassner et al., 2009). In case of indirectly heated gasification, the depleted stream from the gas upgrading is thereby efficiently used as fuel, which allows for limiting the size of the separation system due to a better process integration.

\subsection{Energy-integration model}

As discussed in detail in the applied methodology (Gassner and Maréchal, 2009a), the heat requirements of all process stream determined in the energy-flow models are implemented in the energy-integration model to compute the optimal thermal integration of the process streams and to define the heat recovery potential. First, the temperatures of all hot and cold streams are corrected by minimum approach tem- 
peratures that depend on the type of stream considered ${ }^{2}$ Then, the temperature intervals assembling the streams are identified and the energy cascade of the process is calculated. In general, several possibilities to satisfy the minimum energy requirements are provided. The necessary heat that needs to be supplied above the pinch is usually produced by combustion. If available at a useful temperature, the excess heat below the pinch is recovered in a Rankine cycle for power production, whose superstructure (i.e. the production and usage levels) is predefined in the problem set-up. In this work, a steam cycle with back pressure and condensing turbine stages at efficiencies of $80 \%$ and $70 \%$, respectively, are considered. Depending on the possibility of selling heat in a district heating network, the cycle may be designed for power- or heat-operation. Other utility techniques, like the use of heat pumps, combustion boosting through oxygen injection or air preheating might be used if large quantities of heat are exchanged around the pinch point or if the pinch is situated at a very high temperature level.

A mathematical programming formulation of the optimal integration of utilities has been proposed and detailed in (Maréchal and Kalitventzeff, 1998; Gassner and Maréchal, 2009a). The method allows for computing the optimal flows through the system for maximum combined fuel, power and heat production. In this approach, we consider off-gases and depleted streams from the different process sections as fuel and balance the requirement by withdrawing intermediate product streams from suitable locations. The flow rates of the different sections are thus interdependent with the heating and cooling requirements of the process, and the optimal system is determined by mixed integer linear programming maximising the operating profit from the products.

\subsection{Economic evaluation}

\subsubsection{Approach}

In the design methodology applied here, we consider the thermodynamic conditions to be reached as decision variables. Once these conditions are determined in the flowsheet model, we compute the process performances and estimate its investment cost by sizing the major process equipment that allows to reach the thermodynamic design target. This method differs from the conventional thermo-economic approaches where either the equipment size is considered as a decision variable or the total investment cost is estimated on the components' nominal capacity, as it is done by for example Tijmensen et al. (2002).

The investment estimation presented here is obtained by realizing a simplified sizing of the major process equipment. Considering that the equipment's cost is essentially dependent on its size and construction materials, it is influenced by specific process conditions like temperature, pressure and volume flows. Hence, the information available from flowsheet calculations allow to relate the process investment cost with its thermodynamic operating conditions and performances. This is of great interest with regard to a future thermo-economic optimisation of the installation. Following the method described in (Turton et al., 1998), the total grass roots costs $C_{G R}$ that designate the total investment cost for a new production site, can be correlated to the equipment's purchase cost by (24):

$$
C_{G R}=\left(1+c_{1}\right) \sum_{i} C_{B M, i}+c_{2} \sum_{i} C^{0}{ }_{B M, i}
$$

where $C_{B M, i}^{0}$ is the bare module costs of the equipment $i$ at base case conditions (i.e. ambient operating pressure and carbon steel construction) and $C_{B M, i}$ its cost considering the actual operating conditions. The factors $c_{1}$ and $c_{2}$ represent additional expenses related to the construction of the plant. Following Turton et al. (1998), it is assumed that the costs of auxiliary facilities, site development and buildings are independent on special process conditions and amount to $35 \%$ of the total bare module costs at base case conditions. Contingencies and fees are dependent on these conditions and amount to $18 \%$ of the equipments' total cost. The according numeric values of 0.18 for $c_{1}$ and 0.35 for $c_{2}$ used here provide an investment cost estimation for mature technology and established process engineering.

\footnotetext{
${ }^{2}$ Minimum approach temperature contributions of 8,4 and $2 \mathrm{~K}$ for gaseous, liquid and evaporating or condensing streams are assumed here.
} 
Table 6: Assumptions for process economics.

\begin{tabular}{lr}
\hline Parameter & Value \\
\hline Marshall and Swift index (2006) & 1302 \\
Dollar exchange rate & $1.5 \mathrm{US} \$ / €$ \\
Interest rate & $6 \%$ \\
Discount period & 15 years \\
Plant availability & $90 \%$ \\
Operators & $4 \mathrm{p} . / \mathrm{shift}$ \\
Operator salary & 60 '000€/year \\
Maintenance costs & $5 \% /$ year of $C_{G R}$ \\
Wood price $\left(\Phi_{\text {wood }}=50 \%\right)$ & $33 € / \mathrm{MWh}$ \\
Biodiesel price & $105 € / \mathrm{MWh}$ \\
Electricity price (green) & $180 € / \mathrm{MWh}$ \\
\hline${ }^{a}$ Full time operation requires three shifts per day. With a working time of five days per week and 48 weeks per year, one \\
$\quad$ operator per shift corresponds to 4.56 employees.
\end{tabular}

Unless stated otherwise, the bare module costs of the equipment is determined from correlations given in (Ulrich and Vasudevan, 2004; Turton et al., 1998). For process vessels, maximum diameters of $4 \mathrm{~m}$ (vertical) and $3 \mathrm{~m}$ (horizontal) are assumed, and multiple units operated in parallel are considered if necessary. A complete list of parameters for the investment analysis and the considered prices for wood and electricity are given in Table 6.

\subsubsection{Equipment rating}

Wood Drying The sizing of the direct rotary air dryer is based on an average velocity of wood of $u_{\text {wood }}=0.03 \mathrm{~m} \cdot \mathrm{s}^{-1}$ occupying $12 \%$ of the dryer's cross sectional area (Ulrich and Vasudevan, 2004). Accordingly, the diameter of the drum is given by:

$$
d=2\left(\frac{\dot{m}_{\text {wood }}}{0.12 \Pi \rho_{\text {wood }} u_{\text {wood }}}\right)^{1 / 2}
$$

where $\dot{m}_{\text {wood }}$ and $\rho_{\text {wood }}$ are the mass flow and density of wood respectively. The dryer's length is determined considering an overall heat transfer coefficient in $\mathrm{W} \cdot \mathrm{m}^{-3} \mathrm{~K}^{-1}$ based on the dryers volume as given by (Ulrich and Vasudevan, 2004):

$$
U=240 G^{0.67} / d
$$

where $G$ is the average gas mass flux that is typically in the range of 0.5 to $5 \mathrm{~kg} \cdot \mathrm{s}^{-1} \mathrm{~m}^{-2}$. The dryer's length follows from:

$$
l=\frac{\Delta h_{v a p} \dot{m}_{H 2 O, v a p}}{U A \Delta T_{l m}}
$$

For steam drying fixed bed design is a convenient choice and detailed information about its performance and size is given in (Berghel and Renström, 2002). Assuming the mean velocity of superheated steam being constant during scale-up, the dryer's diameter is calculated with:

$$
d=2\left(\frac{\dot{V}_{\text {steam }}}{\Pi u_{\text {mean }}}\right)^{1 / 2}
$$

where $\dot{V}_{\text {steam }}$ is the volume flow of steam and $u_{\text {mean }}$ its mean velocity. Using the developed energyflow model for steam drying and data from (Berghel and Renström, 2002), a value of $1.4 \mathrm{~m} \cdot \mathrm{s}^{-1}$ has been assessed for the latter. The height of the steam dryer is determined in the same way as for air 
Table 7: Sizing parameters for process reactors. $b=0.188$ is reconciled for the gasification vessel and used for all reactors. Data calculated from (Friedrichs, 1985; Rauch, last visited 04/2009).

\begin{tabular}{lcc}
\hline Reactor type & $u_{\text {mean }}\left[\mathrm{m} \cdot \mathrm{s}^{-1}\right]$ & $h_{0}\left[\mathrm{~m} \cdot\left(\mathrm{m}^{3} \cdot \mathrm{s}^{-1}\right)^{-b}\right]$ \\
\hline Gasification & 0.645 & 4.07 \\
FICFB-combustion & 5.250 & 8.47 \\
Methanation & 0.093 & 18.0 \\
\hline
\end{tabular}

drying and Equations (26) and (27) are used to calculate the overall heat transfer coefficient and the height of the bed. Thereby, the correlation (Eq. 26) has been reconciled with the data given in (Berghel and Renström, 2002) and very good accordance is observed. At an average gas mass flux of 0.645 $\mathrm{kg} \cdot \mathrm{s}^{-1} \mathrm{~m}^{-2}$, the observed value for $U$ amounts to $200 \mathrm{~W} \cdot \mathrm{m}^{-3} \mathrm{~K}^{-1}$, while its calculated value is of 199 $\mathrm{W} \cdot \mathrm{m}^{-3} \mathrm{~K}^{-1}$. Finally, taking the additional height of the dryer's freeboard above the bed into account and preserving the geometry of the considered steam dryer, the overall height of the vessel has been obtained by multiplying the bed height with a factor of 1.27 (Berghel and Renström, 2002). For both the direct rotary air dryer and the fixed bed steam dryer, costing data from (Ulrich and Vasudevan, 2004) have been used.

Gasification and methanation The gasification and methanation reactors are of fluidised bed type and, as it is the case for the steam dryer, their mean gas velocities will typically remain constant during scale-up. The diameter of the reactors are thus calculated according to Equation (28), replacing $\dot{V}_{\text {steam }}$ by the total gas volume flow $\dot{V}_{\text {gas }}$. To calculate the reactor heights, an exponential law of the form:

$$
h=h_{0} \dot{V}_{g a s}^{b}
$$

has been fitted to data from existing plants (Friedrichs, 1985; Rauch, last visited 04/2009). The correlated data for Equations (28) and (29) are given in Table 7.

In order to take the costs associated with the gasification reactor internals and their special construction into account, the costs of the vessels have been multiplied by a factor of 4.4. This value has been derived from the total grass roots costs of the existing FICFB pilot plant, which is of $8 \mathrm{M} €$ for an installation with a nominal capacity of $8 \mathrm{MW}_{t h}$ (Rauch and Hofbauer, 2003). In case of a pressurised gasification, the investment for the biomass feeding system may become substantial and is thus added explicitly. The use of lock hoppers is the most common practice (Wilén and Rautalin, 1993), and a manufacturer's cost estimate reported by Swanson et al. (2002, Appendix G) is used to determine a standard scaling law for a double-train system:

$$
C_{B M, \text { lock hoppers }}=4.3 \cdot 10^{5} \cdot \dot{m}_{d r y}^{0.7} \text { wood }
$$

with $C_{B M, l o c k}$ hoppers in US\$ (2002).

For oxygen supply to directly heated gasification, cost data from (Kirschner, 2009) are used, who reports a range of $0.03-0.70 \mathrm{US} \$ \mathrm{~kg}^{-1}$ (1999) depending on the quantity required. In case production with electrolysis is considered, the bare module cost of the unit is assumed according to the US/DOE target (2010) of $300 \$ \cdot \mathrm{kW}_{e l}^{-1}$ (Newborough, 2004).

Thermal pretreatment before gasification According to a commercial design (Wyssmont Inc., last visited 04/2009), the torrefaction reactor is dimensioned as a vertical tower with a height to diameter ratio of 2, assuming that $20 \%$ of the volume are occupied by the solid with a residence time of $15 \mathrm{~min}$. The purchase cost of the unit has been regressed on the reported $5.65 \cdot 10^{5}$ and $6.70 \cdot 10^{5}$ US $\$$ for units with a volume of 115 and $145 \mathrm{~m}^{3}$, respectively.

For pyrolysis, the design of Henriksen et al. (2006) has been investigated and procedures for a screw conveyor or rotary calcinator are used (Ulrich and Vasudevan, 2004), where the unit size is determined by the required heat transfer through the wall to the solid. With a heat transfer coefficient of 30-100 $\mathrm{kW} \cdot \mathrm{m}^{-2} \cdot \mathrm{K}^{-1}$, scale-up of the pilot plant is however expected to be costly, since either a large temperature difference or heat transfer area is needed. 
Gas cleaning While the cost of a cold gas cleaning system including a cyclone, bag filter, scrubber and guard beds can be estimated from literature data (Ulrich and Vasudevan, 2004), hot gas cleaning technology is still under development and no cost data is currently available. It is therefore assumed that mature hot gas cleaning will roughly follow the same correlation than cold technology, and its cost is evaluated with the same relations using the gas volume flow as parameter. At an assumed temperature of $500^{\circ} \mathrm{C}$, the gas volume flow to be treated is nearly doubled compared to cold processing, which leads to a multiplication of the investment in the order of 1.5.

Carbon dioxide removal The dimensions of the packed tower in the physical absorption process have been calculated according to the method outlined in (Ulrich and Vasudevan, 2004). From the given data, a stage efficiency of $15 \%$ has been determined, and the tower diameter has been dimensioned considering the entrainment limit. The corresponding stripper has not been modelled in detail. As a rule of thumb, its diameter and height have been assumed to be equal to the ones of the absorption tower (Sweny and Valentine, 1970).

The size of the four pressure swing adsorption vessels necessary for continuous operation has been estimated assuming that the required adsorber volume is proportional to the amount of carbon dioxide that needs to be removed from the gas. A typical plant treating $1000 \mathrm{Nm}^{3}$ raw gas per hour with a $\mathrm{CO}_{2}$ content of $40 \% \mathrm{vol}$ is described in (Riquarts and Leitgeb, 1985). The diameter and height of the vessels are reported to be 1.4 and 6 meters, resulting in an specific adsorber volume of $83.13 \mathrm{~m}^{3}$ per $\mathrm{Nm}_{\mathrm{CO} 2}^{3} \cdot \mathrm{s}^{-1}$. The shape of the vessels has been assumed constant and a height to diameter ratio of 4.3 is used.

The purchase cost of the polymeric hollow fibre membranes is estimated by updating the data reported by (Bhide and Stern, 1993), who considered an initial cost for the permeator modules of 108 $\mathrm{US} \$ \cdot \mathrm{m}^{-2}$ and a membrane element cost of $54 \mathrm{US} \$ \cdot \mathrm{m}^{-2}$ that need to be replaced every three years. As detailed in (Gassner et al., 2009), the required membrane area for the separation is directly computed by the design model.

In case of separation by PSA or membranes, the cost for the required TSA unit used for gas drying is determined by assuming a two-column layout with a cycle time of 12 hours and a maximum adsorbent loading of $0.12 \mathrm{~kg}_{\mathrm{H} 2 \mathrm{O}} \cdot \mathrm{kg}_{\text {adsorbent }}^{-1}$ (Ducreux et al., 2006). The cost of the adsorbent and its density have been assumed to $9 \mathrm{US} \$ \cdot \mathrm{kg}^{-1}$ and $800 \mathrm{~kg} \cdot \mathrm{m}^{-3}$, respectively (Ulrich and Vasudevan, 2004).

If $\mathrm{CO}_{2}$-removal is done prior to methanation, the cost estimation of the necessary shift reactor to adjust the stoichiometry is based on the preliminary design and data from (Maréchal et al., 2005).

Heat exchangers and turbomachinery The total cost of the heat recovery system including the heat exchangers of the process and the utility system has been computed from the hot and cold composite curves assuming an overall heat transfer coefficient of $580 \mathrm{~W} \cdot \mathrm{m}^{-2} \mathrm{~K}^{-1}$. The total heat exchange area is distributed over the minimum number of heat exchangers and costing data for fixed tube sheet units from (Ulrich and Vasudevan, 2004) have been used. For turbomachinery, data for mainly centrifugal units are used.

\section{Performance of exemplary technological options}

The outlined thermo-economic model is developed for a systematic process optimisation, which exceeds the scope of this paper and will be presented separately. Here, the modelling approach is thus only illustrated at the example of a few technology scenarios shown in Table 8, which should not be considered as a portfolio of optimal process options. Indirectly heated gasification with air drying and PSA for removing $\mathrm{CO}_{2}$ after methanation is defined as a base scenario (FICFB, base), to which different alternatives are compared. In the scenario (torr), a torrefaction unit is added to the base case, (pM) investigates the influence of a moderately pressurised methanation, and (pM, SA) compares the latter case to one where the stoichiometric number is adjusted to 1 by water-gas shift conversion and $\mathrm{CO}_{2}$-removal prior to methanation. Indirectly heated gasification is then compared to pressurised steam/oxygen-blown gasification and methanation at the same pressure (CFB, pGM), for which the potential improvement by introducing 
Table 8: Process technology and conditions of investigated cases.

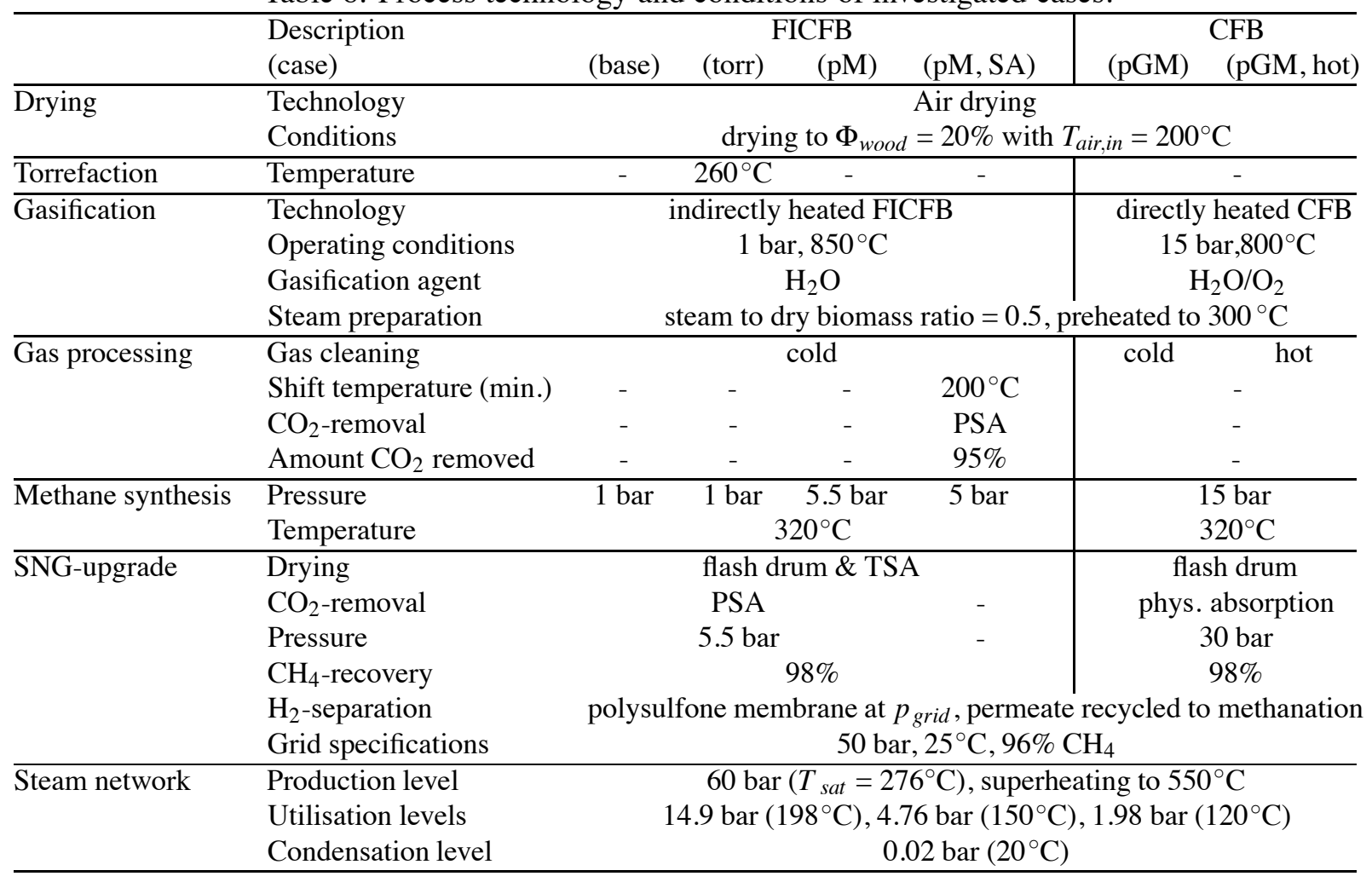

hot gas cleaning is assessed (pGM, hot). In all cases, excess heat is recovered in a steam Rankine cycle, whose production and utilisation levels have been adjusted to reasonably fit the steam demand for gasification and methanation, and providing heat for mainly drying and torrefaction. Heat extraction for district heating is not considered, and a condensation level suitable for the cold utility is used.

\subsection{Energetic performance}

Table 9 shows the overall energy balance and conversion efficiencies of the scenarios defined in Table 8 for a capacity of $20 \mathrm{MW}_{\text {thwood }}$. One integrated composite curves for each gasification technology is given in Figure 6, and Table 10 shows the stream compositions and flows through the systems. Although the energy balances of the different cases seem rather close, some general trends depending on the technology choice can be observed. Due to the higher cold gas efficiency for directly heated gasification assessed in Figure 4, the resulting SNG yield is roughly $10 \%$ higher than in case of indirectly heated gasification. As shown on the composite curve, the indirect heat supply creates a process pinch point at the gasification temperature, and satisfying this heat demand at high temperature requires to withdraw about $19 \%$ of the raw gas production of the gasifier. For this reason, more excess heat is also available below the pinch and leads to a higher co-production of electricity than in directly heated gasification. An alternative to using the excess heat in a Rankine cycle is thereby to recover it in the process through thermal pretreatment. Acting in principle as a chemical heat pump, the endothermal decomposition starts with excess heat from below the pinch, and less heat must be supplied above the process pinch point (Gassner and Maréchal, 2009b). In case of torrefaction, it is necessary to withdraw only $5 \%$ of the raw gas production for satisfying the process energy requirement, which increases the overall SNG-yield from the indirectly heated gasifier by $7 \%$.

While the methanation pressure and prior stoichiometry adjustment influences the energetic performance to a lesser extent, hot gas cleaning is expected to considerable increase the process performance by cogenerating more electricity. Heat losses due to cooling, washing and reheating the gas are avoided, and less steam needs to be prepared for the methanation. More heat can thus be recovered in the Rankine 
Table 9: Useful energy balance and efficiencies of the overall system.

\begin{tabular}{lllrrrrrr}
\hline & & & \multicolumn{3}{c}{ FICFB } & \multicolumn{2}{c}{ CFB } \\
& & & (base) & (torr) & $(\mathrm{pM})$ & $(\mathrm{pM}, \mathrm{SA})$ & $(\mathrm{pGM})$ & (pGM, hot) \\
\hline Consumption & Wood & $\mathrm{kW}$ & $20^{\prime} 000$ & $20^{\prime} 000$ & $20^{\prime} 000$ & $20^{\prime} 000$ & $20^{\prime} 000$ & $20^{\prime} 000$ \\
& Biodiesel & $\mathrm{kW}$ & 365 & 316 & 365 & 365 & 22 & - \\
& Electricity & $\mathrm{kW}$ & - & 63 & - & - & $46^{\mathrm{a}}$ & - \\
\hline Production & SNG & $\mathrm{kW}$ & $13^{\prime} 443$ & $14^{\prime} 318$ & $13^{\prime} 446$ & $13^{\prime} 495$ & $14^{\prime} 765$ & $14^{\prime} 769$ \\
& Electricity & $\mathrm{kW}$ & 609 & - & 521 & 526 & - & $315^{\mathrm{a}}$ \\
\hline Efficiency $^{\mathrm{b}}$ & $\varepsilon$ & $\%$ & 69.0 & 70.3 & 68.6 & 68.8 & 73.6 & 75.4 \\
& $\varepsilon_{\text {chem }}{ }^{\mathrm{c}}$ & $\%$ & 71.3 & 70.1 & 70.5 & 70.8 & 73.5 & 76.6 \\
& $\eta$ & $\%$ & 63.5 & 64.7 & 63.1 & 63.3 & 67.8 & 69.4 \\
\hline
\end{tabular}

a A consumption of $311 \mathrm{~kW}\left(1080 \mathrm{~kJ} \cdot \mathrm{kg}_{O 2}^{-1}\right)$ for off-site oxygen production is included.

${ }^{\mathrm{b}}$ Energy $\varepsilon$ and exergy $\eta$ efficiencies are defined as the ratio between production and consumption terms.

${ }^{c}$ Chemical efficiency: electricity is expressed as SNG-equivalent and substituted therein. An exergy efficiency of 55\% is assumed for the conversion of SNG to electricity.
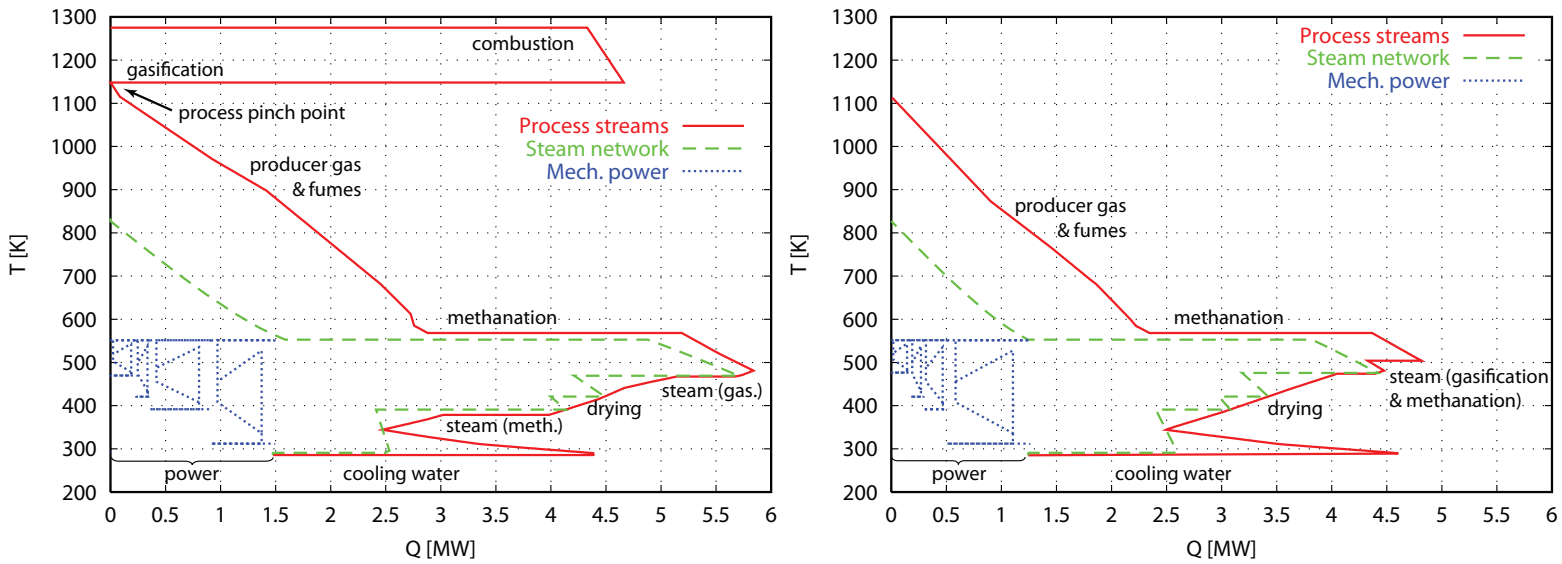

Figure 6: Integrated composite curves for FICFB (base, on the left) and CFB (pGM,hot) for an input of $20 \mathrm{MW}_{\text {th,wood }}$.

cycle, whose gross production increase by $0.5 \mathrm{MW}_{e l}$ and results in an positive electricity balance of the overall system also in case of directly heated gasification with oxygen.

\subsection{Economic performance}

With a common share of $68 \%$ of the total investment of $32.6 \mathrm{M} €$ illustrated in Figure 7, the gasification and methanation sections are dominating the capital costs of the (base)-scenario for FICFB-gasification. As shown in Table 11, atmospheric pressure leads to big reactors due to relatively important volumetric flows, and a much more economic plant design can be obtained by pressurising the reactors. Already at a moderate methanation pressure of 5.5 bar, the investment cost are predicted to decrease by $30 \%$ to 23.4 M€. If directly heated gasification with oxygen is used and the whole system is initially pressurised to 15 bar, a further reduction to $17.9 \mathrm{M} €$ is possible, whereas the pressurised feed train accounts for approximately $10 \%$ of the gasifier cost. If a scale-up to larger plant capacities is considered, operation at atmospheric pressure requires several units in parallel, and a pressurised system seems unavoidable.

Based on the assumptions of Table 6, the share of the depreciated investment and its related maintenance cost is relatively high. At base case conditions, these expenses amount to $47 \%$ of the total production cost. If methanation is moderately pressurised, the expected reduction of the investment allows for decreasing the share of these expenses to $38 \%$ of the total, and leads to a cost reduction by $13 \%$ in absolute terms. In the best performing case of directly heated gasification with hot gas cleaning, the share of investment and maintenance is of only $32 \%$ at $20 \mathrm{MW}_{t h \text {,wood }}$, and can further be reduced to $23 \%$ 
Table 10: Dry gas composition, calorific value and power balance at process section outlets.

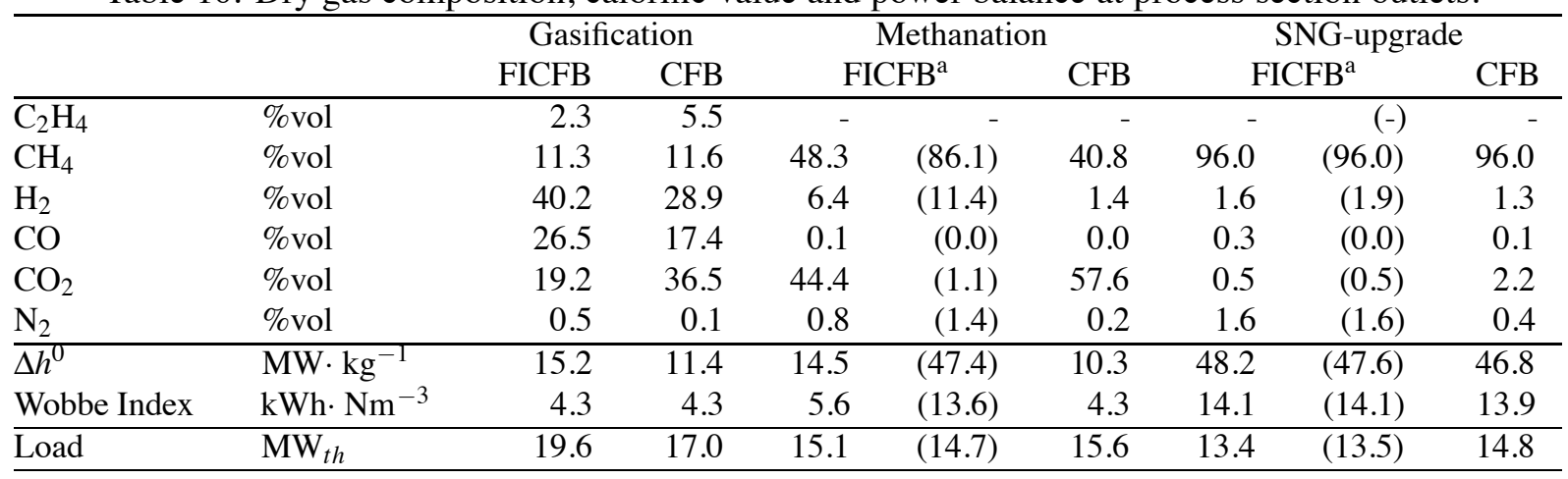

${ }^{\text {a }}$ Values in parenthesis are for $\mathrm{CO}_{2}$-removal before methanation in case (pM, SA).

Figure 7: Investment (left) and total production costs for the scenarios defined in Table 8 at a plant capacity of $20 \mathrm{MW}_{t h \text {,wood }}$. Negative contributions are due to profits from selling electricity.
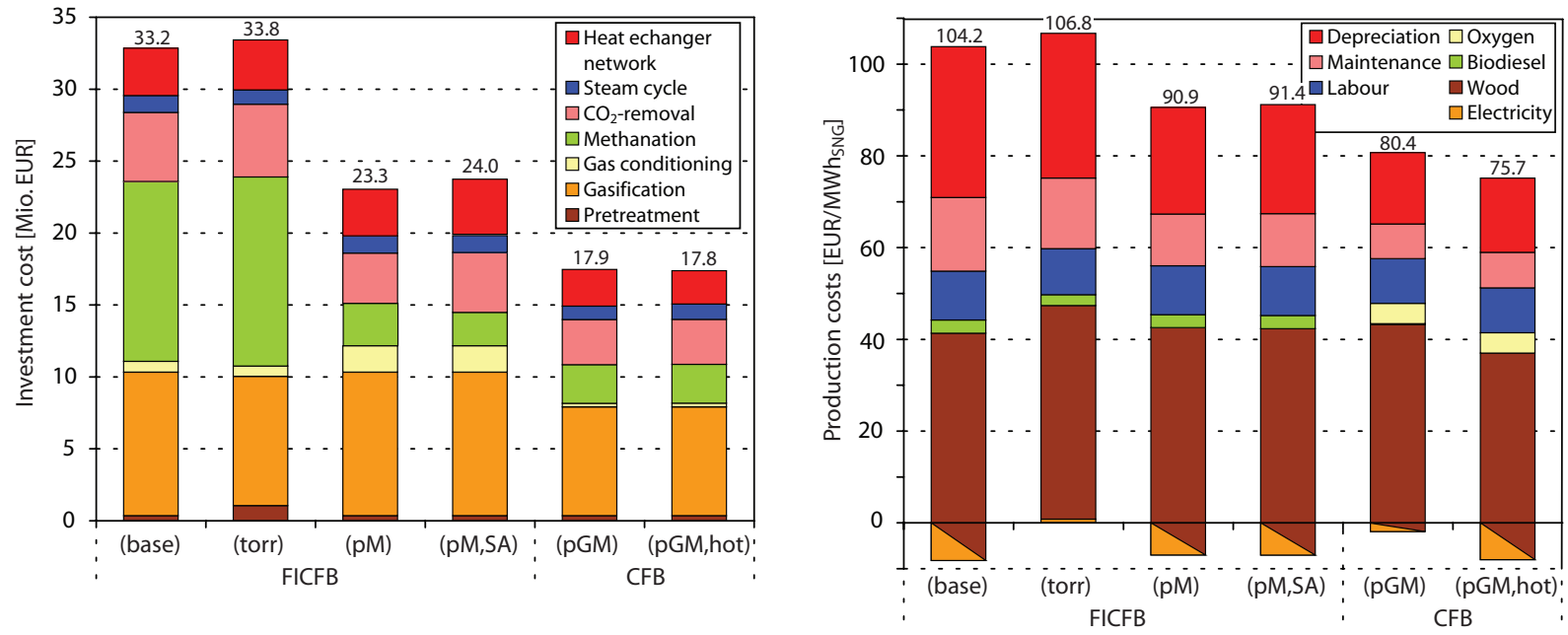

in a plant scale-up to $150 \mathrm{MW}_{\text {th,wood }}$. For this directly heated option, the cost for oxygen is thereby not excessively penalising the plant economics. With the cost data from Kirschner (2009), the required 0.29 $\mathrm{kg} \cdot \mathrm{s}^{-1}\left(820 \mathrm{Nm}^{3} \cdot \mathrm{h}^{-1}\right)$ at $20 \mathrm{MW}_{\text {th,wood }}$ are best supplied by on-site PSA. At this scale, a price of 9.4 cts $\cdot \mathrm{kg}_{O 2}^{-1}$ is obtained, and the expenses for oxygen amount to $4.4 € \cdot \mathrm{MWh}_{S N G}^{-1}$, which correspond to 5-6\% of the total production costs.

Overall, directly heated gasification tends to be the better option, for which total production costs of 80.4 (75.7) $€ \cdot \mathrm{MWh}_{S N G}^{-1}$ with cold (hot) gas cleaning are assessed. For a plant at $150 \mathrm{MW}_{t h \text {,wood }}$, the total costs would reduce to $63.6(58.9) € \cdot \mathrm{MWh}_{S N G}^{-1}$. These numbers are by $10-20 \%$ better than in indirectly heated gasification with moderately pressurised methanation, for which the production costs amount to 90.9 and $80.1 € \cdot \mathrm{MWh}_{S N G}^{-1}$ at 20 and $150 \mathrm{MW}_{\text {th,wood }}$, respectively. Compared with an expected market price of $120 € \cdot \mathrm{MWh}_{S N G}^{-1}$ for the produced green gas, all these options are yet expected to be profitable.

\section{Conclusions}

This paper presented a superstructure based process model for candidate technologies to produce SNG from woody biomass. Based on data from existing plants and pilot installations, simple parametric flowsheet models have been validated and are expected to accurately predict the performances of the installation in a restricted domain of operating conditions. Compared to conventional flowsheet simulation, the proposed model has been developed to assess the thermo-economic performances of the integrated 
Table 11: Reactor size and number of required units for a plant capacity of $20 \mathrm{MW}_{t h \text {,wood }}$ $\mathrm{MW}_{t h, \text { wood }}$, dimensions change).

\begin{tabular}{|c|c|c|c|c|}
\hline & (base) & $\begin{array}{c}\text { FICFB } \\
(\mathrm{pM})\end{array}$ & $(\mathrm{pM}, \mathrm{SA})$ & $\begin{array}{r}\mathrm{CFB} \\
(\mathrm{pGM})\end{array}$ \\
\hline$\overline{N_{g}}$ & $1(8)$ & $1(8)$ & $1(8)$ & $1(1)$ \\
\hline$d_{g} / d_{g, \text { comb. }}$ & & $3.9 \mathrm{~m} / 1.1 \mathrm{~m}$ & & $1.0 \mathrm{~m}$ \\
\hline$h_{g} / h_{g, c o m b .}$ & & $6.0 \mathrm{~m} / 11.6 \mathrm{~m}$ & & $3.5 \mathrm{~m}$ \\
\hline$N_{m}$ & $3(21)$ & $1(4)$ & $1(3)$ & $1(2)$ \\
\hline$d_{m}$ & $3.8 \mathrm{~m}$ & $2.8 \mathrm{~m}$ & $2.5 \mathrm{~m}$ & $1.9 \mathrm{~m}$ \\
\hline$h_{m}$ & $18.2 \mathrm{~m}$ & $16.2 \mathrm{~m}$ & $15.4 \mathrm{~m}$ & $14.0 \mathrm{~m}$ \\
\hline
\end{tabular}

system. It thereby computes not only the energy flow using conventional flowsheeting software, but also the process integration including the combined heat and power production. The energy integration is performed without imposing any restrictions on the process topology, and therefore expected to determine the optimal choice of utilities.

The results of this stepwise flowsheeting are then used to rate the equipment and estimate the investment cost of the system. For these economic calculations, thermodynamic variables like temperature, pressure and volume flows are considered as design specifications to be met, which allows to take the impact of the operating conditions into account. Due to this structure, the process model is adequate for a future thermo-economic optimisation.

In a preliminary screening of the process performance for some typical technology scenarios, it is shown that the conversion of woody biomass to SNG is a viable option with respect to both energetic and economic aspects. Recovering the excess heat by means of a Rankine cycle allows for a considerable co-production of electricity, and overall energy and exergy efficiencies of in the range of 69-76\% and 63$70 \%$, respectively, are obtained. The most efficient conversion is thereby reached with directly heated, steam/oxygen-blown gasification and hot gas cleaning. Due to reduced volume flows, moderately pressurised gasification and methanation is further advantageous with regard to investment cost. Including the equipment's depreciation, total production costs in the range of 76-107 €.MWh $\mathrm{MWG}_{5 N G}^{-1}$ are expected for a plant capacity of $20 \mathrm{MW}_{t h, \text { wood }}$, whereas $59-97 € \cdot \mathrm{MWh}_{S N G}^{-1}$ are assessed for large-scale plants at 150 $\mathrm{MW}_{\text {th,wood }}$ and above.

\section{Acknowledgements}

The authors acknowledge funding provided by the Competence Centre for Energy and Mobility (CCEM), Erdgas Ostschweiz AG, Gasverbund Mittelland AG and Gaznat SA (all Switzerland).

\section{References}

, 2004. Aufdatierung der Standortbestimmung CO2-Gesetz. CO2-Perspektiven und Sensitivitäten. Tech. rep., BFE, Bern.

, 2009. From solid fuels to substitute natural gas (SNG) using TREMP. www.topsoe.com, Haldor Topsøe A/S, Denmark.

Abetz, V., Brinkmann, T., Dijkstra, M., Ebert, K., Fritsch, D., Ohlrogge, K., Paul, D., Peinemann, K.-V., Nunes, S. P., Scharnagl, N., Schossig, M., 2006. Developments in membrane research: From material via process design to industrial application. Advanced Engineering Materials 8, 328-358.

Bacon, D., Downie, J., Hsu, J., Peters, J., 1982. Fundamentals of thermochemical biomass conversion. Elsevier, London, Ch. Modeling of fluidized bed wood gasifiers, pp. 717-732. 
Bart, H.-J., von Gemmingen, U., 2009. Adsorption. In: Ullmann's encyclopedia of industrial chemistry, 7th Edition. Wiley-VCH.

Belsim SA, last visited 04/2009. Vali IV. www.belsim.com.

Berghel, J., Renström, R., 2002. Basic design criteria and corresponding results performance of a pilotscale fluidized superheated atmospheric condition steam dryer. Biomass and Bioenergy 23, 103-112.

Bhide, B., Stern, S., 1993. Membrane processes for the removal of acid gases from natural gas. I. Process configurations and optimization of operating conditions. Journal of Membrane Science 81, 209-237.

Boll, W., Supp, E., Hochgesand, G., Higman, C., Kalteier, P., Müller, W.-D., Kriebel, M., Schlichting, H., Tanz, H., 2009. Gas production, chap. 5: Gas treating. In: Ullmann's encyclopedia of industrial chemistry, 7th Edition. Wiley-VCH.

Bolliger, R., Favrat, D., Maréchal, F., 2005. Advanced power plant design methodology using process integration and multi-objective thermo-economic optimisation. In: Proceedings of the 18th International conference on efficiency, cost, optimization, simulation and environmental impact of energy systems (ECOS).

Bourgois, J., Guyonnet, R., 1988. Characterization and analysis of torrefied wood. Wood Science and Technology 22, 143-155.

Brown, D., 2007. Development and application of an equilibrium reaction modelling approach and of heat integration methodologies for the conceptual design of biomass gasification energy conversion systems. Ph.D. thesis, Tokyo Institute of Technology.

Brown, D., Gassner, M., Fuchino, T., Maréchal, F., 2009. Thermo-economic analysis for the optimal conceptual design of biomass gasification energy conversion systems. Applied Thermal Engineering $29,2137-2152$.

Diab, S., Maddox, R. N., December 1982. Here are the techniques for choosing a solvent and calculating the column size required for a specific process in which a gas is absorbed into a liquid. Chemical Engineering 89 (27), 38-56.

Ducreux, O., Lavigne, C., Nedez, C., 2006. Air and gas drying with activated alumina. www.axens.net, Axens IFP Group Technologies.

Duret, A., Friedli, C., Maréchal, F., 2005. Process design of Synthetic Natural Gas (SNG) production using wood gasification. Journal of Cleaner Production 13, 1434-1446.

Faaij, A., van Ree, R., Waldheim, L., Olsson, E., Oudhuis, A., van Wijk, A., Daey-Ouwens, C., Turkenburg, W., 1997. Gasification of biomass wastes and residues for electricity production. Biomass and Bioenergy 12, 387-407.

Friedli, C., Biollaz, S., 2003. Ecogaz, projet bois-méthane. Tech. rep., EPFL-PSI, Switzerland.

Friedrichs, G., 1985. Methanisierung von Kohlevergasungsgasen im Wirbelbett. PilotEntwicklungsstufe. Tech. rep., Thyssengas Gmbh, Duisburg.

Gassner, M., Baciocchi, R., Maréchal, F., Mazzotti, M., 2009. Integrated design of a gas separation system for the upgrade of crude sng with membranes. Chemical Engineering and Processing, in press.

Gassner, M., Maréchal, F., 2008. Thermo-economic optimisation of the integration of electrolysis in synthetical natural gas production from wood. Energy 33, 189-198.

Gassner, M., Maréchal, F., 2009a. Methodology for the optimal thermo-economic, multi-objective design of thermochemical fuel production from biomass. Computers and Chemical Engineering 33, 769-781. 
Gassner, M., Maréchal, F., 2009b. Thermodynamic comparison of the FICFB and Viking gasification concepts. Energy, in press.

Gil, J., Aznar, M. P., Caballero, M. A., Frances, E., Corella, J., 1997. Biomass gasification in fluidized bed at pilot scale with steam-oxygen mixtures. product distribution for very different operating conditions. Energy and Fuels 11,1109-1118.

Gumz, W., 1950. Gas producers and blast furnaces. Wiley, New York.

Hamelinck, C. N., van Hooijdonk, G., Faaij, A. P., 2005. Ethanol from lignocellulosic biomass: technoeconomic performance in short-, middle- and long-term. Biomass and Bioenergy 28 (4), 384-410.

Henriksen, U., Ahrenfeldt, J., Jensen, T., Gøbel, B., Bentzen, J., Hindsgaul, C., Sørensen, L., 2006. The design, construction and operation of a $75 \mathrm{~kW}$ two-stage gasifier. Energy 31, 1542-1553.

Hersener, J.-L., Meier, U., 1999. Energetisch nutzbares Biomassepotential in der Schweiz sowie Stand der Nutzung in ausgewählten EU-Staaten und den USA. Tech. rep., Bundesamt für Energie, Bern.

Heyne, S., Thunman, H., Harvey, S., 2008. Integration aspects for synthetic natural gas production from biomass based on a novel indirect gasification concept. In: PRES 2008, 11th Conference on Process Integration, Modelling and Optimisation for Energy Saving and Pollution Reduction. Prague.

Hofbauer, H., Rauch, R., Löeffler, G., Kaiser, S., Fercher, E., Tremmel, H., 2002. Six years experience with the FICFB-gasification process. In: Proceedings of the 12th European Conference and Technology Exhibition on Biomass for Energy, Industry and Climate Protection. Amsterdam, Netherlands.

Höhlein, B., Niessen, H., Range, J., 1984. Methane from synthesis gas and operation of high-temperature methanation. Nuclear Engineering and Design 78, 241-250.

Huang, H., Ramaswamy, S., 2009. Modeling biomass gasification using thermodynamic equilibrium approach. Applied Biochemistry and Biotechnology 154, 14-25.

Jarungthammachote, S., Dutta, A., 2007. Thermodynamic equilibrium model and second law analysis of a downdraft waste gasifier. Energy 32, 1660-1669.

Kersten, S., 2002. Biomass gasification in circulating fluidized beds. Ph.D. thesis, Twente University, Enschede.

Kirschner, M. J., 2009. Oxygen. In: Ullmann's encyclopedia of industrial chemistry, 7th Edition. Wiley$\mathrm{VCH}$.

Krischer, O., 1978. Die wissenschaftlichen Grundlagen der Trocknungstechnik. Springer-Verlag, Berlin.

Leibold, H., Hornung, A., Seifert, H., 2008. Hthp syngas cleaning concept of two stage biomass gasification for ft synthesis. Powder Technology 180, 265-270.

Li, X. T., Grace, J. R., Lim, C. J., Watkinson, A. P., Chen, H. P., Kim, J. R., 2004. Biomass gasification in a circulating fluidized bed. Biomass and Bioenergy 26, 171-193.

Luterbacher, J., Fröling, M., Vogel, F., Maréchal, F., Tester, J. W., 2009. Hydrothermal gasification of waste biomass: Process design and life cycle assessment. Environmental Science and Technology 43, $1578-1583$.

Maréchal, F., Kalitventzeff, B., 1998. Process integration: Selection of the optimal utility system. Computers and Chemical Engineering 22, S149-S156.

Maréchal, F., Palazzi, F., Godat, J., Favrat, D., 2005. Thermo-economic modelling and optimisation of fuel cell systems. Fuel Cells 5, 5-24. 
Mozaffarian, M., Zwart, R. W. R., 2003. Feasibility of biomass/waste-related SNG production technologies. Tech. rep., ECN, Petten.

Newborough, M., 2004. A report on electrolysers, future markets and the prospects for ITM Power LTD's electrolyser technology. www.h2fc.com/newsletter.

Newman, S. A., 1985. Acid and sour gas treating processes. Gulf Publishing Company, Houston.

Ondrey, G., 2008. Chementator: Cleaning syngas at high temperatures. Chemical Engineering 115 (12), 11.

Pellegrini, L. F., de Oliveira Jr., S., 2007. Exergy analysis of sugarcane bagasse gasification. Energy 32, 314-327.

Pettersen, T., Lien, K., 1994. A new robust design model for gas separating membrane modules, based on analogy with counter-current heat exchangers. Computers and Chemical Engineering 18 (5), 427-439.

Pfeifer, C., Hofbauer, H., 2008. Development of catalytic tar decomposition downstream from a dual fluidized bed biomass steam gasifier. Powder Technology 180, 9-16.

Pierucci, S., Ranzi, E., 2008. A general mathematical model for a moving bed gasifier. Computer Aided Chemical Engineering 25, 901-906.

Pilarczyk, E., Henning, K.-D., 1987. Natural gas from landfill gases. Resources and Conservation 14, 283-294.

Prins, M. J., Ptasinski, K. J., Janssen, F. J., 2004. Exergetic optimisation of a production process of Fischer-Tropsch fuels from biomass. Fuel Processing Technology 86, 375-389.

Prins, M. J., Ptasinski, K. J., Janssen, F. J. J. G., 2006. More efficient biomass gasification via torrefaction. Energy 31, 3458-3470.

Prins, M. J., Ptasinski, K. J., Janssen, F. J. J. G., 2007. From coal to biomass gasification: Comparison of thermodynamic efficiency. Energy 32, 1248-1259.

Pröll, T., Hofbauer, H., 2008. H2 rich syngas by selective co2 removal from biomass gasification in a dual fluidized bed system - process modelling approach. Fuel Processing Technology 89, 1207-1217.

Rapagnà, S., Jand, N., Kiennemann, A., Foscolo, P., 2000. Steam-gasification of biomass in a fluidisedbed of olivine particles. Biomass and Bioenergy 19, 187-197.

Rauch, R., last visited 04/2009. www.ficfb.at.

Rauch, R., written around 2004. Stromerzeugung aus Biomasse durch Wasserdampfvergasung. Tech. rep., Institut für Verfahrens-, Brennstoff- und Umwelttechnik, TU Wien, www.ficfb.at, last visited 04/2009.

Rauch, R., Hofbauer, H., 2003. Wirbelschicht-Wasserdampf-Vergasung in der Anlage Güssing. Betriebserfahrungen aus zwei Jahren Demonstrationsbetrieb. In: 9. Internationale Fachtagung "Energetische Nutzung nachwachsender Rohstoffe". Freiberg, Deutschland.

Rauch, R., Hofbauer, H., Bosch, K., Siefert, I., Aichernig, C., Tremmel, H., Voigtlaender, K., Koch, R., Lehner, R., 2004. Steam gasification of biomass at CHP plant Guessing - status of the demonstration plant. In: 2nd World Conference and Technology Exhibition on Biomass for Energy, Idustry and Climate Protection. Rome.

Reimert, R., 1985. Methanol production based on synthesis gas from coal and biomass. In: Synthetic fuels. ECSC, Brussels. 
Reimert, R., Schaub, G., 2009. Gas production, chap. 4: Gas production from coal, wood, and other solid feedstocks. In: Ullmann's encyclopedia of industrial chemistry, 7th Edition. Wiley-VCH.

Riquarts, H.-P., Leitgeb, P., 1985. Druckwechsel-Adsorptionsanlagen zur Methangewinnung aus Biogasen. GWF-Gas/Erdgas 126, 15-19.

Sander, R., 1999. Compilation of Henry's law constants for inorganic and organic species of potential importance in environmental chemistry (vers. 3). www.henrys-law.org, last visited 04/2009.

Schuster, G., Löffler, G., Weigl, K., Hofbauer, H., 2001. Biomass steam gasification - an extensive parametric modeling study. Bioresorce Technology 77, 71-79.

Stahl, M., Granström, K., Berghel, J., Renström, R., 2004. Industrial processes for biomass drying and their effects on the quality properties of wood pellets. Biomass and Bioenergy 27, 621-628.

Stucki, S., 2005. Projet bois-methane. Rapport sur la clôture de la phase 1 du projet: Preuve de la faisabilité technique à l'échelle du laboratoire. Tech. rep., PSI, Villigen, Switzerland.

SVGW, 2008. G13, Richtlinien für die Einspeisung von Biogas ins Erdgasnetz. Zürich.

Svoboda, K., Pohǒrelý, M., Hartman, M., Martinec, J., 2009. Pretreatment and feeding of biomass for pressurized entrained flow gasification. Fuel Processing Technology 90, 629-635.

Swanson, M. L., Musich, M. A., Schmidt, D. D., Schultz, J. K., 2002. Feed system innovation for gasification of locally economical alternative fuels (FIGLEAF). final report. Tech. Rep. DE-FC2600NT40904, US Department of Energy.

Sweny, J. W., Valentine, J. P., 1970. Physical solvent stars in gas treatment / purification. Chemical Engineering 77, 54-56.

Szargut, J., Styrylska, T., 1964. Angenäherte Bestimmung der Exergie von Brennstoffen. BrennstoffWärme-Kraft 16, 589-636.

Tijmensen, J. A. M., Faaij, A. P. C., Hamelinck, C. N., van Hardeveld, M. R. M., 2002. Exploration of the possibilities for production of Fischer Tropsch liquids and power via biomass gasification. Biomass and Bioenergy 23, 129-152.

Torres, W., Pansare, S. S., Goodwin Jr., J. G., 2007. Hot gas removal of tars, ammonia, and hydrogen sulfide from biomass gasification gas. Catalysis Reviews - Science and Engineering 49, 407-456.

Turton, R., Bailie, R. C., Whiting, W. B., Shaeiwitz, J. A., 1998. Analysis, synthesis, and design of chemical processes. Prentice Hall, New York.

Ulrich, G. D., Vasudevan, P. T., 2004. Chemical engineering process design and economics. A practical guide, 2nd Edition. Process publishing, New Hampshire.

UOP LLC, last visited 04/2009. www.uop.com/gasprocessing/6010.html.

van Stein, E. E., Juwono, E., Demetri, E. P., 2002. The impact of ITM oxygen on economics for coalbased IGCC. In: Proceedings of the 27th International Technical Conference on Coal Utilization \& Fuel Systems. Clearwater, Florida.

Wilén, C., Rautalin, A., 1993. Handling and feeding of biomass to pressurized reactors: Safety engineering. Bioresource Technology 46, 77-85.

Wyssmont Inc., last visited 04/2009. www.techtp.com. 
Zhang, S., Maréchal, F., Gassner, M., Périn-Levasseur, Z., Qi, W., Ren, Z., Yan, Y., Favrat, D., 2009. Process modeling and integration of fuel ethanol production from lignocellulosic biomass based on double acid hydrolysis. Energy and Fuels 23, 1759-1765.

Zhang, S., Yan, Y., Li, T., Ren, Z., 2005. Upgrading of liquid fuel from the pyrolysis of biomass. Bioresource Technology 96, 545-550. 